\title{
Hydrothermal carbonate chimneys from a continental rift (Afar Rift): Mineralogy, geochemistry, and mode of formation
}

\author{
V.M. Dekov ${ }^{a}{ }^{*}$, N.M. Egueh ${ }^{\mathrm{a}, \mathrm{b}, \mathrm{c}}$, G.D. Kamenov ${ }^{\mathrm{d}}$, G. Bayon ${ }^{\mathrm{a}}$, S.V. Lalonde ${ }^{\mathrm{b}}$, M. Schmidt $^{\mathrm{e}}$,

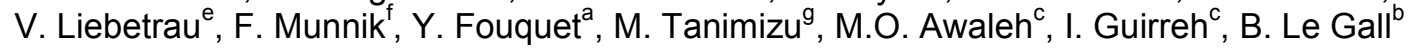

\author{
a Laboratoire de Géochimie et Métallogénie, Département Géosciences Marines, IFREMER, Z.I. Pointe du diable, \\ BP 70-29280 Plouzané, France \\ ${ }^{\mathrm{b}}$ CNRS UMR 6538 Laboratoire Domaines Océaniques, Institut Universitaire Européen de la Mer, Université de \\ Brest, Place Nicolas Copernic, 29280-Plouzané, France \\ ' IST, Centre d'Etude et de Recherche de Djibouti (CERD), BP 486, Route de l'Aéroport, Djibouti \\ d Department of Geological Sciences, University of Florida, 241 Williamson Hall, Gainesville, FL 32611, USA \\ e Helmholtz Centre for Ocean Research Kiel, GEOMAR, Wischhofstr. 1-3, D-24124 Kiel, Germany \\ $\mathrm{f}$ Institute of Ion Beam Physics and Materials Research, Helmholtz-Zentrum Dresden-Rossendorf, D-01328 \\ Dresden, Germany \\ ${ }^{g}$ Kochi Institute for Core Sample Research, JAMSTEC, Japan
}

*: Corresponding author : V.M. Dekov, email address : Vesselin.Dekov@ifremer.fr

\begin{abstract}
:
Carbonate chimney-like deposits up to $60 \mathrm{~m}$ high are scattered or arranged in rows at the shores of a desiccating hypersaline and alkaline lake from a continental rift setting (Lake Abhé, Afar Rift, Djibouti). The chimneys formed sub-aqueously in the lake water body at a higher water level than observed today. Alternating calcite and low-Mg calcite + silica concentric layers compose the chimney structures. Mineralogical and geochemical investigations of the chimneys, lake water, and hot spring (hydrothermal) fluids suggest that the chimneys are a result of rapid carbonate precipitation during the mixing of hydrothermal fluids with lake water. In contrast to the hot spring fluid, lake water is enriched in HREE and possesses a pronounced positive $\mathrm{Ce}$ anomaly, features that are preserved in the carbonate chimney layers. Mixing calculations based on $\mathrm{Sr}$ - isotope and concentration data indicate a hydrothermal fluid contribution of $\sim 45 \%$ in the chimney interior, which decreases to $\sim 4 \%$ in the external chimney layer. $\mathrm{Sr}$ in the hydrothermal fluids is predominantly leached from the underlying volcanic rocks, whereas the lake's Sr budget is dominated by riverine input. Considering the fluid mixing ratios calculated by $\mathrm{Sr}$-data, the measured $\mathrm{C}$ and $\mathrm{O}$ isotope compositions indicate that chimney carbonates precipitated at temperatures between $14{ }^{\circ} \mathrm{C}$ (internal part) and $22{ }^{\circ} \mathrm{C}$ (external part) with $\delta^{13} \mathrm{C}$-carbonate mainly controlled by isotope equilibrium exchange of lake water with atmospheric $\mathrm{CO}_{2}$. The low-Mg calcite layers, including the outermost layer, have enhanced signals of lake water inheritance based on elevated concentrations of immobile elements, $\Sigma \mathrm{REE}$, and $\mathrm{Sr}$ and $\mathrm{Ca}$ isotope compositions. Ca-isotope data reveal that internal chimney layers formed by non-equilibrium calcite precipitation with a predominantly hydrothermal Ca source. The external low-Mg calcite layer received $\mathrm{Ca}$ contributions from both hydrothermal fluid and lake water, with the latter being the dominant $\mathrm{Ca}$ source. Highly positive $\delta^{44 / 40} \mathrm{Ca}$ of lake water likely reflects non-equilibrium Ca-carbonate precipitation during lake water evaporation with resulting ${ }^{44} \mathrm{Ca}$ enrichment of residual lake water. The strong degree of ${ }^{44} \mathrm{Ca}$ enrichment may point towards multiple lake drying and Ca-reservoir depletion events. Coupled
\end{abstract}


C-O-Ca-isotope data of the sampled carbonate chimney suggest late-stage (low-temperature) hydrothermal carbonate chimney formation during strongly evaporative lake conditions at the time of low-Mg calcite precipitation. U-Th age dating suggests the chimneys formed no earlier than $0.82 \mathrm{kyr}$ BP $(0.28 \pm 0.54)$.

\section{Highlights}

- giant (up to $60 \mathrm{~m}$ high) chimney-like carbonate deposits formed in a continental rift chimneys formed sub-aqueously in a desiccating hypersaline and alkaline lake they are a result of carbonate precipitation during mixing hydrothermal fluids - lake water there is a dominant lake water control on deposition of chimney exterior the chimneys formed recently: $\sim 0.28 \pm 0.54 \mathrm{kyr}$ BP.

Keywords : carbonate ; Chimney ; continental rift ; H-C-O-Ca-Sr-Nd-Pb-Th-U-isotopes ; hydrothermalism

\section{Introduction}

Since the discovery of hydrothermal activity at seafloor spreading centers (Corliss et al., 1979 and Spiess et al., 1980), over 300 seafloor vent fields have been investigated in diverse settings spanning oceanic ridges, volcanic arcs, and hot spots (Hannington et al., 2011). While 
hydrothermalism and related mineral deposits have been well characterized in oceanic extensional settings (German and Von Damm, 2004), little is known regarding hydrothermal activity and deposits in areas of continental break-up and at the transition from continental rifting to seafloor spreading. Only a few works address sub-lacustrine hydrothermal activity in active continental rifts: e.g., the East African Rift system [Lakes Tanganyika (Tiercelin et al., 1989; 1993; Pflumio et al., 1994; Barrat et al., 2000), Malawi (Müller and Förstner, 1973; Branchu et al., 2005) and Bogoria (Renaut et al., 2013)], the Baikal Rift (Crane et al., 1991; Granina et al., 2007), and the Basin and Range Province (western United States) (Bischoff et al., 1993; Benson, 1994; Rosen et al., 2004).

Sub-lacustrine hydrothermal activity in the East African Rift system is particularly interesting due to its diverse tectonic settings. The southern part of the East African Rift (e.g., Tanganyika and Malawi Lakes) is a typical continental rift with thinned continental crust (Tiercelin et al., 1988), whereas the northern part (Afar Rift) constitutes the best modern example of a transition from continental rifting to incipient oceanic spreading (Ebinger and Casey, 2001). Despite significant efforts to investigate the tectonics and volcanism of the Afar Rift (De Chabalier and Avouac, 1994; Deniel et al., 1994; Hayward and Ebinger, 1996; Beyene and Abdelsalam, 2005; Wright et al., 2006; Bastow and Keir, 2011; Moucha and Forte, 2011), hydrothermal activity and associated deposits remain uncharacterized [excluding drilled geothermal wells (Fouillac et al., 1989; D’Amore et al., 1998)]. Recent (from 4000 B.P. onward; Gasse and Street, 1978) and progressive desiccation of the alkaline, salty Lake Abhé located in the Afar Rift reveals an impressive picture of sub-lacustrine hydrothermal activity: large, tower-like carbonate deposits (the majority are $1-20 \mathrm{~m}$ high and $5-15 \mathrm{~m}$ in diameter at the base; the largest, named As Bahalto, is $\sim 60 \mathrm{~m}$ tall and $\sim 90 \mathrm{~m}$ in diameter) are scattered or grouped in rows and groves on the dry lake bottom (Fig. 1 A,B,C) and the summits of some are steaming. These towers resemble low-temperature freshwater deposits called tufa that form, for example, in alkaline and salty lakes of the Basin and Range Province (Bischoff et al., 1993; Rosen et al., 2004), however their geothermal association and scarcity of plant or animal matter make them more properly considered travertine (Ford and Pedley, 1996).

In order to better understand the composition and mode of formation of hydrothermal carbonate deposits in a continental rift setting, we describe here the results of a multi-proxy, elemental, isotopic, and mineralogical investigation of an inactive hydrothermal chimney system, along with its associated modern fluids, at Lake Abhé in the Afar Rift. 


\section{Geological setting}

Lake Abhé (Afar Rift) is located at the triple junction between two nascent mid-oceanic ridges (Red Sea and Gulf of Aden) and a continental rift [Main Ethiopian Rift (MER)] (Fig. 2 A). The lake occupies the western part of the closed Gob Aad tectonic basin (Fig. 2 B) (Beyene and Abdelsalam, 2005). It is the most elevated basin within a series of fan-arranged fault-controlled depressions (Fig. 2 B). Whereas the easternmost Asal Rift (Fig. 2 B) is known to be the onshore prolongation of the westward propagating Tadjoura Rift, the structural context of the Gob Aad basin is debatable. The Gob Aad basin has developed on a volcanic basement composed mainly of basalts (2.17-1.86 Ma) and subordinate acidic rocks during Pleistocene-Holocene times (Barberi and Varet, 1977). These lavas represent the upper unit of the trap-like Stratoid Series that floors a major part of the Afar Rift (Barberi and Varet, 1977; Gasse et al., 1987). The Pleistocene-Holocene sediments (mainly lacustrine) in the Gob Aad basin are slightly deformed and post-date a N100 E-trending horst-graben network comprising the highly fissured Stratoid basalts (Demange and Stieljes, 1975). The oldest sediments exposed at the surface are of Early Pleistocene age: (a) lacustrine shales interstratified within Upper Stratoid basaltic lava flows ( 2 Ma), and (b) calcareous diatomites, gypsum, and ash flows (Gasse and Street, 1978). The horst bordering the Gob Aad basin (Fig. 2 B) is composed of Stratoid lavas ( $<3 \mathrm{Ma}$ ) and felsic domes, whereas the Lake Abhé floor is furnished entirely by Stratoid basalts (Deniel et al., 1994).

The hyperalkaline $(\mathrm{pH}=10)$ and salty $([\mathrm{Na}]=13.3 \mathrm{ppt})$ Lake Abhé has substantially fluctuated in volume and surface elevation during the Quaternary (Gasse, 1977). Its evolution during the Late Pleistocene is marked by three successive transgressions (Demange et al., 1971). Two Holocene episodes of high-water levels are identified at 11-9 ka and 8-4 ka (Fontes and Pouchan, 1975; Gasse et al., 1987). The lake is mainly recharged by the Awash River draining the Ethiopian Plateau $(\sim 2500 \mathrm{~m})$. The recently shrinking lake water body exhibits salt flats with hundreds of huge $(<60 \mathrm{~m})$ tower-like structures aligned generally WNW-ESE, parallel to the regional extensional fault network (Fig. 2 B) (Demange and Stieljes, 1975) and scattered on the east, south and west shores. Numerous hot springs $\left(\mathrm{T}<100^{\circ} \mathrm{C}\right)$ jet around the chimneys' bases.

\section{Samples and methods}

\subsection{Samples and mineralogical studies}


We studied the spire (\#DJ-19-07) of an inactive conical (1.80 m high, $\sim 0.90 \mathrm{~m}$ diameter at the base) carbonate chimney $\left(11^{\circ} 08^{\prime} 49.8^{\prime \prime} \mathrm{N}, 41^{\circ} 52^{\prime} 51.9^{\prime \prime E}\right.$; Fig. 2 B, 3 A) after cross-cutting it and selecting six samples (\#DJ-19-07-1, -2, -3, -4, -5, -6; hereafter named \#\#1, 2, 3, 4, 5, 6) (using a diamond mini drill) from six zones across the chimney (Fig. 3 B). The sampled chimney was from a group of several inactive chimneys aligned in a row and located at $\sim 1 \mathrm{~km}$ distance from the Lake Abhé. Fluids from both a hot $\left(\mathrm{T}=98.6^{\circ} \mathrm{C} ; 11^{\circ} 08^{\prime} 50.9^{\prime \prime} \mathrm{N}, 41^{\circ} 52^{\prime} 52.8^{\prime \prime} \mathrm{E}\right)$ and cold $\left(\mathrm{T}=37^{\circ} \mathrm{C} ; 11^{\circ} 08^{\prime} 41.4^{\prime \prime} \mathrm{N}, 41^{\circ} 52^{\prime} 54.1^{\prime \prime} \mathrm{E}\right)$ spring located nearby the chimney, as well as surface water from Lake Abhé, were also analyzed. Solid samples were ground into a fine powder in an agate mortar for further analysis. Thin and polished sections from the same cross-section were investigated by optical microscopy (Olympus BX60 polarizing microscope) for mineral composition and texture.

Secondary electron images (SEI) and energy dispersive X-ray spectra (EDS) were obtained on small $(\sim 1 \mathrm{x} 1 \mathrm{~cm})$ sub-samples from both the internal and external part of the chimney using a FEI Quanta 200 scanning electron microscope (SEM) $(\mathrm{V}=10 \mathrm{kV}, \mathrm{I}=100 \mu \mathrm{A}$, electron beam diameter of $2 \mu \mathrm{m}$ ), after mounting of sub-samples on aluminum stubs using carbon tape and coating with $\mathrm{Au}$.

Internal textures of the chimney were analyzed in polished sections using Particle Induced X-ray Emission (PIXE), Rutherford Backscattering Spectroscopy (RBS), and X-ray mapping. PIXE and RBS applied a $3 \mathrm{MeV} \mathrm{H}^{+}$beam focussed to $\sim 5 \mu \mathrm{m}$ and scanned over various areas of the sample. A Ketek Silicon drift detector collimated to $80 \mathrm{~mm}^{2}$ was used to detect the Xrays emitted from the sample. The detector was placed outside the sample chamber, necessitating two Be windows with a total thickness of $150 \mu \mathrm{m}$ and a $6 \mathrm{~mm}$ layer of air (Herrmann and Grambole, 1995). In addition, a $100 \mu \mathrm{m}$ Mylar absorber was placed in front of the detector to suppress dominant X-rays from Ca. Data maps of X-ray or RBS counts as a function of the position were directly obtained from the measurements. For the $\mathrm{Ba} L, \mathrm{Mn} K$, and $\mathrm{Fe} K$ lines, prominent $\mathrm{Ca} K \mathrm{X}$-rays increased background up to two times, and a background subtraction was applied to correct for this contribution. For O, a near surface region in the RBS spectrum was employed and a background subtraction made for the presence of $\mathrm{Ca}$ based on simple extrapolation. Maps of raw counts were converted to semiquantitative maps of concentration by extracting calibration values from the quantitative analysis of PIXE and RBS spectra taken from selected regions in the map.

X-ray mapping (in $\mathrm{Ca} K_{\alpha}, \mathrm{Mg} K_{\alpha}$, and $\mathrm{Si} K_{\alpha}$ lines) and concentrations of elements with $\mathrm{Z} \geq 9$ were acquired on $\mathrm{C}$-coated polished thin sections using Cameca SX 100 electron 
microprobe $(\mathrm{EMP})(\mathrm{V}=15 \mathrm{keV}, \mathrm{I}=20 \mathrm{nA}$, electron beam diameter of $2 \mu \mathrm{m})$. Standards used were: wollastonite $\left(\mathrm{Ca} K_{\alpha}\right.$, Si $\left.K_{\alpha}\right)$, forsterite $\left(\mathrm{Mg} K_{\alpha}\right), \mathrm{Al}_{2} \mathrm{O}_{3}\left(\mathrm{Al} K_{\alpha}\right), \mathrm{BaSO}_{4}\left(\mathrm{Ba} L_{\alpha}\right), \mathrm{FeS}_{2}(\mathrm{~S}$ $\left.K_{\alpha}, \mathrm{Fe} K_{\alpha}\right), \mathrm{TiMnO}\left(\mathrm{Mn} K_{\alpha}\right), \mathrm{ZnS}\left(\mathrm{Zn} K_{\alpha}\right)$, apatite (P $\left.K_{\alpha}\right)$, Cu metal $\left(\mathrm{Cu} K_{\alpha}\right)$, Ni metal (Ni $K_{\alpha}$ ), and $\mathrm{Cr}$ metal $\left(\mathrm{Cr} K_{\alpha}\right.$ ), and detection limits (wt.\%) were 0.04 for $\mathrm{Ca}, 0.03$ for $\mathrm{Si}, 0.01$ for $\mathrm{Mg}, 0.03$ for $\mathrm{Al}, 0.13$ for $\mathrm{Ba}, 0.03$ for $\mathrm{S}, 0.05$ for $\mathrm{Fe}, 0.06$ for $\mathrm{Mn}, 0.13$ for $\mathrm{Zn}, 0.03$ for P, 0.08 for $\mathrm{Cu}, 0.08$ for $\mathrm{Ni}$, and 0.05 for $\mathrm{Cr}$.

Mineral composition of finely powdered samples was determined by X-ray diffraction (XRD) analysis (Philips X-ray diffractometer PW 1820 with monochromatic Co $K_{\alpha}$ radiation) of random mounts with scans from 4 to $75^{\circ} 2 \theta$, with $0.02^{\circ} 2 \theta$ step, and $1 \mathrm{~s} / \mathrm{step}$. XRD patterns were interpreted by using the XPowder ${ }^{\circledR}$ software.

\subsection{Major and trace element composition}

The bulk chemical composition of the chimney samples was determined by Inductively Coupled Plasma Optical Emission Spectrometry (ICP-OES) (major elements: Al, Fe, K, Mg, Si, Ti) and by Inductively Coupled Plasma Mass Spectrometry (ICP-MS) [trace elements: As, $\mathrm{Ba}, \mathrm{Co}, \mathrm{Cr}, \mathrm{Cs}, \mathrm{Cu}, \mathrm{Ge}, \mathrm{Hf}, \mathrm{Li}, \mathrm{Mn}, \mathrm{Mo}, \mathrm{Nb}, \mathrm{Ni}, \mathrm{Pb}, \mathrm{Rb}, \mathrm{Sb}, \mathrm{Sc}, \mathrm{Se}, \mathrm{Sn}, \mathrm{Sr}, \mathrm{Ta}, \mathrm{Th}, \mathrm{Tl}, \mathrm{U}, \mathrm{V}$, $\mathrm{Y}, \mathrm{Zn}, \mathrm{Zr}$; and rare earth elements (REE): La, Ce, Pr, Nd, Sm, Eu, Gd, Tb, Dy, Ho, Er, Tm, $\mathrm{Yb}, \mathrm{Lu}]$. Concentrations of $\mathrm{Ca}$ were calculated by isotope mass balance after double spike $\mathrm{Ca}$ isotope analysis (see section 3.3.4).

All chemicals used in the ICP-OES and ICP-MS analyses were of suprapure quality. For ICP-OES analyses, $\sim 100 \mathrm{mg}$ of sample powder was weighed in Teflon vials, dissolved in conc. $\mathrm{HNO}_{3}$, evaporated to dryness on a hot $\left(90^{\circ} \mathrm{C}\right)$ plate, redissolved in conc. $\mathrm{HF}$ and diluted to $0.05 \% \mathrm{HF}$. The ICP-OES instrument (Horiba) was calibrated with matrix-matched solutions prepared by mixing mono-elemental standards and diluting to appropriate concentrations $(0,1$, and $10 \mathrm{ppm})$. For ICP-MS analyses of elements other than Ba, REE, and Y, 25-65 mg of sample were weighed in Teflon vials, dissolved overnight in $\mathrm{HF}: \mathrm{HNO}_{3} 2: 1$ (2 $\mathrm{mL})$ and evaporated to dryness on a hot $\left(90^{\circ} \mathrm{C}\right)$ plate. Samples were then redissolved in aqua regia $(2 \mathrm{~mL})$, evaporated to dryness on a hot $\left(90^{\circ} \mathrm{C}\right)$ plate, and finally redissolved in conc. $\mathrm{HNO}_{3}(1 \mathrm{~mL})$ and diluted to $5 \% \mathrm{HNO}_{3}$ with a $10 \mathrm{ppb}$ In internal standard to correct for instrument drift. The ICP-MS instrument (ThermoScientific Xseries II; operating with collision cell) was calibrated using BHVO-2 solutions digested with the same protocol. For $\mathrm{Ba}$, REE, and $\mathrm{Y}$, carbonates were dissolved in acetic acid and spiked with $\mathrm{Tm}$ as per 
Rongemaille et al. (2011). REE and Y were separated and pre-concentrated according to the column exchange procedure of Barrat et al. (1996), and post-column digest solutions were analysed using a Thermo Scientific Element2 High Resolution Inductively Coupled Plasma Mass Spectrometry (HR-ICP-MS). Data were collected in low resolution mode for sensitivity and corrected for oxide and hydroxide interferences by analyzing solutions of ultra-pure $\mathrm{H}_{2} \mathrm{O}$, $\mathrm{Ba}+\mathrm{Ce}, \mathrm{Pr}+\mathrm{Nd}$ and $\mathrm{Sm}+\mathrm{Gd}+\mathrm{Tb}$ (Barrat et al., 1996; Bayon et al., 2009a). Concentrations were calculated using the Tm-addition method (Bayon et al., 2011; Freslon et al., 2011).

Fluid samples were filtered through $0.25-\mu \mathrm{m}$ (Nuclepore filters) at the time of collection, acidified with concentrated $\mathrm{HNO}_{3}$, and stored in high-density polyethylene (HDPE) vials until analysis. For elements other than REE, Y and Th, samples were diluted by weight with 5\% $\mathrm{HNO}_{3}$ and analyzed using ThermoScientific Element2 ICP-MS at medium resolution with Re and $\mathrm{Rh}$ as internal standards to correct for instrument drift. Quantification of the results was achieved via external calibration using a set of gravimetrically prepared dilutions of commercial ICP-MS standards (SPEX CertiPrep, Inc.). The reported concentration values are better than $\pm 5 \%$. REE, Y, and Th were pre-concentrated from 25 -mL fluid samples using $\mathrm{Mg}$ hydroxide (hot spring fluid) and Fe-hydroxide (lake water and cold spring fluid) coprecipitation techniques, following procedures described in Freslon et al. (2011) and Bayon et al. (2011), respectively, and analyzed by Element2 HR-ICP-MS as described above for carbonate digests.

\subsection{Isotopic compositions}

\subsection{1. $\mathrm{H}, \mathrm{C}$ and $\mathrm{O}$ isotopes}

For $\mathrm{C}$ and $\mathrm{O}$ isotope composition of chimney carbonate samples, $\mathrm{CO}_{2}$ was released from finely powdered samples by reaction with $100 \% \mathrm{H}_{3} \mathrm{PO}_{4}$ at $72^{\circ} \mathrm{C}$ in the Carbo Kiel IV preparation line. $\mathrm{CO}_{2}$ was isotopically analyzed using a Finnigan MAT 253 mass spectrometer. ${ }^{18} \mathrm{O} /{ }^{16} \mathrm{O}$ and ${ }^{13} \mathrm{C} /{ }^{12} \mathrm{C}$ ratios were determined against a working calcite standard and are expressed in the common $\delta$-notation relative to Vienna Pee Dee Belemnite (VPDB). Precision for $\delta^{18} \mathrm{O}$ and $\delta^{13} \mathrm{C}$ was $0.16 \%$ o $(2 \sigma)$ and $0.04 \%$ o $(2 \sigma)$, respectively. No further corrections for different acid fractionation factors were applied for the low-Mg calcite sample.

Lake Abhé water and hot spring fluid $\mathrm{H}$ and $\mathrm{O}$ isotopic values were measured using a Picarro L2120-I Isotopic Liquid Water and Water Vapor Analyzer coupled with a Picarro A0211 High Precision Vaporizer and a CTC HTS PAL autosampler. Samples and standards were run in duplicate. Results were standardized based on two internal University of Florida 
water standards (Beta and Gamma) that were calibrated using international standards (VSMOW, VSLAP, and VGISP). All isotope results are reported in standard delta notation relative to Vienna Standard Mean Ocean Water (VSMOW) with $0.1 \%$ ( $2 \sigma)$ error for the $\delta^{18} \mathrm{O}$ and $0.5 \%(2 \sigma)$ error for $\delta \mathrm{D}$.

\subsection{2. $\mathrm{Sr}, \mathrm{Nd}$ and $\mathrm{Pb}$ isotopes}

Sample preparation for $\mathrm{Sr}, \mathrm{Nd}$ and $\mathrm{Pb}$ isotope analysis was done in a clean lab environment with Optima-grade reagents and the isotope ratios were determined on a "Nu-Plasma" Multiple Collector Inductively Coupled Plasma Mass Spectrometry (MC-ICP-MS) (Kamenov et al., 2008). The reported ${ }^{87} \mathrm{Sr} /{ }^{86} \mathrm{Sr}$ ratios are relative to NBS $987{ }^{87} \mathrm{Sr} /{ }^{86} \mathrm{Sr}=0.71025$ $( \pm 0.00003,2 \sigma) . \mathrm{Nd}$ isotope compositions are relative to $\mathrm{JNdi}-1{ }^{143} \mathrm{Nd} /{ }^{144} \mathrm{Nd}=0.51215$ $( \pm 0.000018,2 \sigma)$. Epsilon $\mathrm{Nd}$ values were calculated with present day Chondritic Uniform Reservoir ${ }^{143} \mathrm{Nd} /{ }^{144} \mathrm{Nd}=0.512638$ (Wasserburg and DePaolo, 1979). Pb isotope data are relative to the following values of NBS 981: ${ }^{206} \mathrm{~Pb} /{ }^{204} \mathrm{~Pb}=16.937 \quad( \pm 0.004, \quad 2 \sigma)$, ${ }^{207} \mathrm{~Pb} /{ }^{204} \mathrm{~Pb}=15.490( \pm 0.003,2 \sigma)$, and ${ }^{208} \mathrm{~Pb} /{ }^{204} \mathrm{~Pb}=36.695( \pm 0.009,2 \sigma)$.

\subsubsection{U-Th isotope measurements and age calculation}

About $50 \mathrm{mg}$ of each chimney sample were digested using double-subboiled $\mathrm{HNO}_{3}$ after addition of a mixed ${ }^{236} \mathrm{U}^{229} \mathrm{Th}$ spike for $\mathrm{U}-\mathrm{Th}$ isotope investigations (Bayon et al., 2009b). In addition, $\mathrm{U}$ isotopic ratios were determined on the lake water and hydrothermal fluid samples. $\mathrm{U}$ and Th were separated chemically using conventional anion exchange techniques (Edwards et al., 1986), and their concentrations and isotope ratios were measured by "Neptune" MCICP-MS. Carbonate ages were determined with an isochron method using the ISOPLOT program (v. 3.71, Ludwig, 2009). This approach was required due to the incorporation of inherited ${ }^{232} \mathrm{Th}$ into the carbonate matrix.

\subsubsection{Ca isotopes}

For Ca isotope analyses $20 \mathrm{mg}$ of the external layer (\#DJ-19-07-6) and of the central zone (\#DJ-19-07-1) of the chimney were dissolved in $2.25 \mathrm{~N} \mathrm{HNO}_{3}$ at room temperature. All chemical preparations were done in a laminar flow bench within clean lab facilities using acids purified by a 2 -step Teflon cascade still. After no remaining residues could be observed, aliquots of $3000 \mathrm{ng}$ Ca equivalent of these solutions as well as of hot spring fluid and of lake water were mixed with a ${ }^{43} \mathrm{Ca} /{ }^{48} \mathrm{Ca}$ double spike and evaporated. The lake water sample contained particles and was centrifuged prior to spiking and evaporation. Whether or not 
secondary isotope fractionating processes occurred on particle surfaces, or they formed after the original field sampling, could not be verified. However, after spiking, the observed tendency of precipitation during acidification and heating could be regarded as insignificant for isotope values due to double spike normalization. The samples were treated with a mixture of $0.75 \mathrm{~mL} 8 \mathrm{~N} \mathrm{HNO}_{3}$ and $0.25 \mathrm{~mL} \mathrm{H}_{2} \mathrm{O}_{2}$ for at least $12 \mathrm{~h}$ at $80^{\circ} \mathrm{C}$ to remove any potential organics. After drying and re-suspension in $2.2 \mathrm{~N} \mathrm{HNO}_{3}$, procedures for $\mathrm{Ca}$ extraction with MCI-Gel, isotope measurement with a Finnigan Triton Thermal Ionisation Mass Spectrometer (TIMS), and data reduction were followed as described by Heuser et al. (2002) and Böhm et al. (2006). Isotope data are reported as $\delta^{44 / 40} \mathrm{Ca}(\%)$ relative to the NIST standard SRM915a, where $\delta^{44 / 40} \mathrm{Ca}=\left[\left({ }^{44} \mathrm{Ca} /{ }^{40} \mathrm{Ca}\right)_{\text {sample }} /\left({ }^{44} \mathrm{Ca} /{ }^{40} \mathrm{Ca}\right)_{\text {SRM915a - }}\right]$ x 1000 . Bracketing standards $(\mathrm{n}=4)$ during this session showed a 2 SEM of $0.11 \%$, which is typical for this method and measurement facility. All sample measurements reproduced better than this (at $n=3$ and 2, respectively), and the mean values of a whole procedure (WP) reproducibility test for the innermost chimney sample differed by $0.01 \%$, identical to typical WP-blanks of $30 \mathrm{ng}$.

\section{Results}

\subsection{Mineralogy}

The outer surface of the inactive chimneys is botryoidal, grayish- to brownish-white (Figs $1 \mathrm{C}, 3 \mathrm{~A}$ ), whereas their internal parts are porous and white (Fig. $3 \mathrm{~B}$ ). In cross-section the texture is concentric, with porous, white zones separated by thin, dense, grayish- to brownishwhite layers (Fig. 3 B). The white layers (\#DJ-19-07-1, -2, -3, -5) are composed of calcite [XRD and EMP (1.07 wt.\% $\mathrm{MgCO}_{3}$, average of 22 point analyses) data] and show skeletal, hollow crystals arranged in rows (Fig. 3 C, D). The main elements (Ca, Sr, O, Mn) which comprise these layers are homogenously distributed across them (Fig. 4 A, B, C, D). The botryoidal surface layer (and internal brownish-white layers) of the chimney (\#DJ-19-07-6, 4) consists of low-Mg calcite [estimated by XRD using the $d_{104}$ shift compared to pure calcite (Goldsmith et al., 1969; Lumsden, 1979) and direct EMP measurements yielding 4.68 wt.\% $\mathrm{MgCO}_{3}$ (average of 26 point analyses)]. These layers are enriched in $\mathrm{Ba}$ and Fe (Fig. $4 \mathrm{E}, \mathrm{F}$ ). $\mathrm{X}$-ray mapping of calcite layers at a micrometer scale reveals that they are not composed of pure calcite. The skeletal calcite crystals have delicate concentric zones of low-Mg calcite, which is mainly concentrated at their surfaces where it forms 3-5 $\mu \mathrm{m}$ thick rims (Fig. 5 A, B). 
These rims contain 2-5 wt.\% Si (Fig. 5 C). The content of low-Mg calcite in the calcite layers is below 5\% (detection limits of XRD).

\subsection{Geochemistry}

Hot spring fluid is slightly basic $(\mathrm{pH}=7.9)$ with higher concentrations of $\mathrm{Ca}, \mathrm{Sr}, \mathrm{As}, \mathrm{Ba}$, $\mathrm{Mn}, \mathrm{Cu}, \mathrm{Co}, \mathrm{Pb}$ and $\mathrm{V}$ compared to the lake water, which is basic $(\mathrm{pH}=10)$ and enriched in $\mathrm{Na}, \mathrm{K}, \mathrm{Mg}, \mathrm{Fe}, \mathrm{Cr}$, Ni and $\mathrm{Zn}$ (Table 1). Cold spring fluid is slightly basic with $\mathrm{pH}=8.8$. Lake water shows pronounced HREE enrichment, a positive Ce anomaly, and is richest in $\mathbf{\Sigma}$ REE, $\mathrm{Y}$, and Th (but lower in $\mathrm{La}, \mathrm{Pr}$ and $\mathrm{Nd}$, which have the highest concentrations in cold spring fluid) (Fig. 6 A). Hot and cold spring fluid both show relatively flat LREE/HREE distributions, but differ significantly in that hot spring fluid has significantly lower $\Sigma$ REE and may possess a small positive Eu anomaly (Table 1). Like modern seawater (Bau et al., 1996), lake water and cold spring fluid possess positive Y/Ho ratios, whereas hot spring fluid shows the reverse. Positive La and Gd anomalies, features also characteristic of modern seawater (Bau et al., 1996), are absent or minor in all samples.

Elemental distribution across the chimney is complex. For all trace elements besides Ba, Y, and REE, data were derived from total sample digests in $\mathrm{HNO}_{3}-\mathrm{HF}$ in order to reveal wholerock compositions that include detritally-sourced elements normally insoluble in weaker (e.g., acetic acid) attacks. The calcite layers (\#DJ-19-07-1, -2, -3, -5) are richer in Ca and Ni than the botryoidal, low-Mg calcite layers (\#DJ-19-07-6, -4), which are enriched in $\mathrm{Mg}, \mathrm{Sr}, \mathrm{Si}, \mathrm{Al}$, Hf, Nb, Th, Y, Ba, Mn, Ge, Sb, Se, Pb, Rb, Cs, Sn, Cu, V and REE (Table 1). Fe, As, Co, Tl and $U$ have bimodal distributions with maximums in both the central calcite part $(\# \# 1,2)$ and the low-Mg calcite surface layer (\#6). The central calcite zone (\#1) is the most rich in $\mathrm{Zn}$, whereas the other internal zones \#\# 2, 3 (calcite) and 4 (low-Mg calcite) are enriched in Li. The external low-Mg calcite layer (\#6) is the richest in $\mathrm{Ti}, \mathrm{Cr}, \mathrm{Zr}$ and Mo. This layer along with the zone beneath it (\#5, calcite) has maximum concentrations of Sc and Ta (Table 1).

For $\mathrm{Ba}, \mathrm{Y}$, and REE, data obtained after acetic acid digestion were employed to examine signals in authigenic carbonate components. Carbonate chimney samples show broadly similar REE patterns, however low-Mg calcite samples (\#DJ-19-07-6, -4) are enriched in REE by around an order of magnitude relative to pure calcite samples. All the chimney layers show varying heavy $\mathrm{REE}$ enrichment $\left(\mathrm{La}_{\mathrm{SN}} / \mathrm{Lu}_{\mathrm{SN}}<1\right)$ and show no significant Eu anomalies (Table 1; Fig. 6 A). Plot of Ce/Ce* vs $\mathrm{Pr} / \mathrm{Pr}$ * (Fig. 6 B) distinguishes between true positive and negative Ce anomalies and those that may arise from La anomalies (Bau and Dulski, 1996). 
The Lake Abhé carbonate chimneys have true positive Ce anomalies $\left(\mathrm{Ce} / \mathrm{Ce}^{*}>1, \operatorname{Pr} / \operatorname{Pr} *<1\right)$ (Fig. 6 B). Hot and cold spring fluids possess no Ce anomalies, whereas surface lake water shows an extreme positive Ce anomaly. For comparison, hydrothermal carbonate chimneys from the more pH-neutral Lake Tanganyika, East African Rift ( $\mathrm{pH}=8.6-8.9$; Barrat et al., 2000) are also plotted in Fig. 6 B, and present true negative anomalies.

\subsection{Isotope composition}

\subsection{1. $\mathrm{H}, \mathrm{C}$, and $\mathrm{O}$ isotopes}

The stable O-isotope analyses performed on one pure calcite sample (\#DJ-19-07-1) and one low-Mg calcite sample (\#DJ-19-07-6) reveal $\delta^{18} \mathrm{O}$-values of 1.54 and $4.73 \%$ VPDB, respectively (Table 2). Stable C-isotope values of 2.00 and $4.17 \%$ were determined for the internal (\#DJ-19-07-1) and the external (\#DJ-19-07-6) chimney sample, respectively. Oxygen $(+6.7 \%)$ and hydrogen $(+39.6 \%)$ isotope composition of one Lake Abhé water sample strongly deviates from the fluid composition $\left(\delta^{18} \mathrm{O}=-3.2 \%\right.$; $\delta \mathrm{D}=-24.9 \%$ ) sampled from a nearby hot spring (Table 2).

\subsection{2. $\mathrm{Sr}, \mathrm{Nd}$ and $\mathrm{Pb}$ isotopes}

There are relatively small variations in the $\mathrm{Nd}$ isotopes, ranging from 1.7 to $2.7 \varepsilon \mathrm{Nd}$ (Table 2). $\mathrm{Pb}$ isotopes also show relatively similar values in zones \#1 to \#5 whereas external zone \#6 shows distinctly different $\mathrm{Pb}$ isotopes (Table 2). In contrast, $\mathrm{Sr}$ isotopes show bimodal distribution with lower ${ }^{87} \mathrm{Sr} /{ }^{86} \mathrm{Sr}$ in zones \#1 to \#3 and higher ${ }^{87} \mathrm{Sr} /{ }^{86} \mathrm{Sr}$ in zones \#4 to \#6 (Table 2). ${ }^{87} \mathrm{Sr} /{ }^{86} \mathrm{Sr}$ in hot spring fluid is lower and ${ }^{87} \mathrm{Sr} /{ }^{86} \mathrm{Sr}$ in Lake Abhé water is higher compared to the values observed in the carbonate chimney samples (Table 2). These two fluids are the possible end-members contributing $\mathrm{Sr}$ to the carbonate chimneys. Mixing calculations based on the $\mathrm{Sr}$ concentrations and $\mathrm{Sr}$ isotope data for these two end-members indicate $45-42 \%$ hot spring fluid contribution in zones \#1 to \#3 and 10-3.6 \% for zones \#4 to \#6 (Fig. 7).

\subsection{3. $U$ and Th isotopes}

${ }^{238} \mathrm{U}$ and ${ }^{232} \mathrm{Th}$ concentrations in the chimney samples range from $\sim 330$ to $1050 \mathrm{ppb}$ and 300 to $4300 \mathrm{ppb}$, respectively (Table 2$)$. The ${ }^{238} \mathrm{U}$ concentration in the lake water $(\sim 138 \mathrm{ppb})$ is much higher than in the cold spring fluid ( $\sim 1 \mathrm{ppb})$. This is in agreement with previous studies that have reported high U contents in hypersaline lake environments (Simpson et al., 
1980; Linhoff et al., 2011). $\delta^{234} U$ values for the chimney samples range from 327 to $338 \%$ (i.e., ${ }^{234} \mathrm{U} /{ }^{238} \mathrm{U}$ activity ratios of 1.327 and 1.338 , respectively; Table 2), lower than that for the hydrothermal fluid $\left[\left({ }^{234} \mathrm{U} /{ }^{238} \mathrm{U}\right)=\sim 1.464\right]$, but similar to that for the lake water $(\sim 1.322)$. These results clearly show that a large fraction of $U$ incorporated into the carbonate chimneys is derived from the lake water rather than from the hydrothermal fluids. All chimney samples exhibit very similar $\left({ }^{230} \mathrm{Th} /{ }^{232} \mathrm{Th}\right.$ ) ratios at near secular equilibrium value (average $1.19 \pm$ $0.02 ; 2 \sigma)$, and define an isochron on a $\left({ }^{230} \mathrm{Th} /{ }^{232} \mathrm{Th}\right)$ versus $\left({ }^{238} \mathrm{U} /{ }^{232} \mathrm{Th}\right)$ plot (Fig. 8). Assuming that all the studied samples were formed near contemporaneously (i.e., within error), the carbonate age determined by an isochron method is very recent (i.e., $0.28 \pm 0.54$ kyr BP). Repeated U-Th analyses of an in house cold seep carbonate standard over the same period of measurements gave an estimated external reproducibility on calculated isochron UTh ages of about $25 \%$ (Bayon et al., 2013).

\subsubsection{Ca isotopes}

$\delta^{44 / 40} \mathrm{Ca}$ shows significant differences between carbonate chimney samples, with no values overlapping within the external reproducibility of $0.11 \%$ (Table 2$)$. The central zone (\#1; $\delta^{44 / 40} \mathrm{Ca}=0.60 \%$ ) has a value $\sim 1.1 \%$ lower than that of the external layer $\left(\# 6, \delta{ }^{44 / 40} \mathrm{Ca}=\right.$ $1.71 \%$ o). The hot spring fluid $\left(\delta^{44 / 40} \mathrm{Ca}=0.90 \%\right.$ o $)$ lies in between these precipitates and matches, when referenced to seawater (SW) instead of NIST, data published for the endmember composition of a Mid-Atlantic Ridge hydrothermal system [-0.95 $\pm 0.07 \%$ o (SW); Amini et al., 2008] and for Bulk Earth [-0.92 \pm 0.18 \%o (SW); Skulan et al., 1997], assuming a SW signature around $1.8 \%$ (NIST-915). In contrast, the centrifuged lake water plots far from all other samples with an exceptional high $\delta^{44 / 40} \mathrm{Ca}$ value of $3.45 \%$ (Table 2). The latter value requires independent verification on additional samples as secondary precipitation may have occurred on particles after field sampling and could have shifted the remaining aqueous phase towards heavier signatures by extracting preferentially lighter isotopes. Therefore, the lake water data rather represent a maximum $\delta^{44 / 40} \mathrm{Ca}$ value for the purposes of discussion.

\section{Discussion}

\subsection{Formation of continental rift chimneys: mineralogical and geochemical evidence}

The vertical, conical geometry of these carbonate deposits suggests they formed underwater, not subaerially. Recent maximum depth of Lake Abhé is $37 \mathrm{~m}$, but its water body 
has experienced substantial fluctuations, from almost total desiccation to as deep as $\sim 210 \mathrm{~m}$ during the Late Pleistocene-Holocene, in response to climatic changes (Fontes and Pouchan, 1975; Gasse and Street, 1978). The carbonate chimneys most likely formed during the interaction of hydrothermal fluids with lake water, similar to the tufa towers of alkaline lakes in the Basin and Range Province where $\mathrm{CO}_{3}$-rich lake waters mix with Ca-rich groundwater discharge (Bischoff et al., 1993; Rosen et al., 2004). The alignment of chimneys in WNWESE-oriented rows (Fig. 1 A) suggests that they formed along active faults (clearly depicted on the DEM in Figure 2 B) that likely operated as steep pathways for percolating fluids.

The carbonate chimneys' internal framework of skeletal calcite crystals suggests they are a result of rapid precipitation under disequilibrium conditions (e.g., Jones and Renaut, 1996). This also points to the mixing of hydrothermal fluid with lake water as the likely scenario for carbonate chimney formation. Such a scenario is also consistent with the REE and Sr isotope data (Figs $6 \mathrm{C}$ and 7). Using this "black smoker" type mixing model for precipitation and growth of the carbonate chimneys, we can estimate that $\mathrm{Ca}, \mathrm{Sr}, \mathrm{As}, \mathrm{Ba}, \mathrm{Cu}, \mathrm{Co}, \mathrm{Pb}$ and $\mathrm{V}$ were largely derived from hydrothermal fluid whereas lake water served as the major source for $\mathrm{Na}, \mathrm{K}, \mathrm{Mg}, \mathrm{Fe}, \mathrm{Mn}, \mathrm{Cr}, \mathrm{Ni}$ and $\mathrm{Zn}$ (Table 1). The two different types of chimney zones, distinct in mineralogy and geochemistry [calcite $(\# \# 1,2,3,5)$ and low-Mg calcite $(\# \# 4,6)]$, imply: (1) precipitation under different conditions; (2) secondary redistribution of the elements across the chimney; or (3) the combined effect of both processes. As discussed below, elevated terrigenous element concentrations in the low-Mg calcite zones, and possible contamination by anthropogenic $\mathrm{Pb}$ in the case of the low-Mg calcite external layer (\#6), suggest that lake regression and perhaps even subaerial exposure after lake dessication may have played a role in chimney zonation.

The considerable amount of $\mathrm{Si}$ in the chimney external layer $(2.69 \%$, \#6; Table 1) implies that $\mathrm{Si}$ is in a Si-containing phase rather than as an admixture in low-Mg calcite. Due to charge and ionic radii differences, $\mathrm{Si}^{4+}(r=0.48 \AA$ in six-fold coordination; Whittaker and Muntus, 1970) substitution for $\mathrm{Mg}^{2+}(r=0.80 \AA$ in six-fold coordination; Whittaker and Muntus, 1970) or $\mathrm{Ca}^{2+}(r=1.08 \AA$ in six-fold coordination; Whittaker and Muntus, 1970) in the low-Mg calcite crystal lattice seems unlikely. Since no Si mineral was detected by the XRD (detection limits $>5 \%$ ), $\mathrm{Si}$ may be present as amorphous $\mathrm{SiO}_{2}$. Using the $\mathrm{Si}$ concentration (determined by ICP-OES), we calculated $5.75 \% \mathrm{SiO}_{2 \mathrm{am}}$. in the chimney external layer, which is at about the detection limit of XRD. High concentrations of silica are typical of seafloor black smoker-type hydrothermal systems (both fluids and deposits) (German and Von Damm, 2004). Evidence shows that conductive cooling of the 
hydrothermal fluid combined with fluid-seawater mixing results in silica supersaturation and deposition of $\mathrm{SiO}_{2 \mathrm{am}}$. (Herzig et al., 1988). In Lake Abhé, dissolved silica concentrations are well above $\mathrm{SiO}_{2 \mathrm{am}}$. saturation today, although they have not always been so (Gasse, 1977). Thus, at least in the case of the Si-enriched, low-Mg calcite external layer, Si-rich hydrothermal fluid may not be required to explain the $\mathrm{SiO}_{2 \mathrm{am}}$. enrichments, although at the same time it cannot be ruled out. At the interface external chimney layer/ambient lake water, low-Mg calcite precipitates as a result of mixing between the Ca-rich vent fluid and Mg- and $\mathrm{HCO}_{3}{ }^{-}$-rich lake water (Gasse and Street, 1978). Continuous $\mathrm{SiO}_{2 a m}$. precipitation may act to armor the external zone and to provide a geochemical sink for some elements (e.g., Fe, Mn, $\mathrm{Cu}, \mathrm{Mo}, \mathrm{V}, \mathrm{REE}$ ). Internal layers of low-Mg calcite (\#4) mark former chimney surfaces with increased $\mathrm{Mg}$ and $\mathrm{Si}$ flux and low-Mg calcite and $\mathrm{SiO}_{2 \mathrm{am}}$. deposition. The intimate intergrowth (on sub-micrometer scale) of low- $\mathrm{Mg}$ calcite and $\mathrm{SiO}_{2 \mathrm{am}}$. in the thin rims around the calcite crystals (Fig. 5 B, C) suggests that these minerals are coeval. High concentrations of terrigenous elements (Al, Hf, Nb, Th, Y and $\mathrm{Sn}$ in \#\#4 and 6, and Ti, Cr, Zr, Sc and Ta in \#6) may indicate an enhanced contribution from lake water on the precipitation of these layers. Dominant lake water control on the deposition of low-Mg calcite layers is further suggested by high content of some mobile elements enriched in the alkaline lake water, notably $\mathrm{Rb}$ and $\mathrm{Cs}$ (Table 1). Although lake water was likely a more important source of elements to these layers, they are also richer in some elements carried mainly by the hydrothermal fluids ( $\mathrm{Sr}, \mathrm{Ba}, \mathrm{Mn}, \mathrm{Pb}, \mathrm{Cu}, \mathrm{V}$ and presumably $\mathrm{Sb}, \mathrm{Se}$ and $\mathrm{Ge}$ ) relative to the internal, pure calcite zones (Table 1). We suppose that these elements may have been coprecipitated with or scavenged on low- $\mathrm{Mg}$ calcite $+\mathrm{SiO}_{2}$ am. more efficiently than the case of pure calcite. In other words, the low-Mg calcite layers may have had a higher affinity for these elements.

Unlike seafloor hydrothermal systems, continental rift hydrothermal systems in Lake Abhé area are not capable of supplying considerable amounts of base metals to the surface, and as a consequence the continental rift "smokers" are poor in base metals (Table 1). Based on studies of geothermal wells drilled in the Afar Rift (Fouillac et al., 1989; D'Amore et al., 1998) we speculate that the base metal load of continental rift hydrothermal systems is discharged in the subsurface. However, the continental rift "smokers" have contents of Li (6.3-15.2 ppm) an order of magnitude higher than those of "black smokers" from mid-ocean ridges and back-arc spreading centers (0.1-1.6 ppm; Zeng et al., 2009a,b). This seems reasonable if we presume the upper continental crust (UCC) and mid-ocean ridge basalts (MORB) have been the sources of metals for the continental rift and mid-ocean ridge 
hydrothermal systems, respectively. The UCC contains about an order of magnitude more Li than the MORB $\left(\mathrm{Li}_{\mathrm{UCC}}=35\right.$ ppm, Teng et al., 2004; $\mathrm{Li}_{\mathrm{MORB}}=5.6 \mathrm{ppm}$, Ryan and Langmuir, 1987).

The extreme positive Ce anomaly observed for Lake Abhé surface water is comparable in magnitude to that observed in highly alkaline ( $\mathrm{pH}=9.4-9.8)$ Lake Van (Turkey) where such an anomaly was first described and attributed to the formation of (penta)carbonato-Ce(VI) complexes (Möller and Bau, 1993). The absence of comparable positive Ce anomalies in similar rift-hosted carbonate chimneys from Lake Tanganyika (East African Rift; Barrat et al., 2000) may be attributed to its lower $\mathrm{pH}$ and decreased $\mathrm{CO}_{3}{ }^{2-}$ activity relative to Lake Abhé. Enhanced alkalinity and accompanying changes in aqueous carbonate complexation may similarly account for the HREE enrichment observed in lake water and in all chimney samples (e.g., Pourret et al., 2007; Rongemaille et al., 2011). The positive Ce anomalies and HREE enrichment observed for all studied chimney layers (Fig. 6 A, B) support Sr mixing calculations and clearly indicate a signficant contribution from $\mathrm{Ce}$ - and HREE- enriched alkaline lake water. The significantly higher $\Sigma$ REE and differences in the HREE patterns of the low-Mg carbonates (Fig. 6 A; Table 1) may represent formation during periods of different lake alkalinity and/or lake level.

\subsection{Isotopic constraints on the chimney formation}

The scenario of carbonate chimney formation (see sub-section 5.1) can be further refined using the $\delta \mathrm{D}, \delta^{13} \mathrm{C}$ and $\delta^{18} \mathrm{O}$ data of carbonate samples and lake water (Table 2). The actual isotope composition of Lake Abhé water and spring fluid (Table 2) is compared to data derived from an extensive sampling campaign in the 1970's (Fontes et al., 1980). The $\delta^{18} \mathrm{O}$ and $\delta \mathrm{D}$ values of spring fluid measured in this study plot well within the field of data previously published for Lake Abhé hydrothermal springs (Fig. 9). The spring fluid is thought to originate from local meteoric water modified by water/rock interaction (Fontes et al., 1980). This causes a horizontal deviation from the global meteoric water line (GMWL) to more positive $\delta^{18} \mathrm{O}$ values of water (Fig. 9). The recent Lake Abhé water is enriched in both $\delta \mathrm{D}$ and $\delta^{18} \mathrm{O}$ compared to the lake water composition in 1975 (Fig. 9). This deviation can be explained by higher evaporation in recent times. Moreover, the generally positive $\delta^{18} \mathrm{O}$ and $\delta \mathrm{D}$ values of lake water could be explained by early stage condensation of monsoon rains (Fontes et al., 1980). 
The $\delta^{18} \mathrm{O}$ trend across the chimney [from lighter (central part) to heavier (external part) values (Table 2)] could be a result of precipitation from different fluid sources or from the same fluid, but at varying temperature. The Sr-isotope studies strongly suggest a carbonate precipitation from a mixed fluid composed of two components (hydrothermal fluid and lake water) with varying proportions. Accepting the calculated fluid mixing ratio, e.g., \#1 layer has precipitated from a mixture of $45 \%$ hot spring fluid and 55\% lake water (Fig. 7), the Oisotope composition of the fluid from which \#1 precipitated can be calculated by:

$\delta^{18} \mathrm{O}_{\text {precipitating fluid }}=0.45 \times \delta^{18} \mathrm{O}_{\text {hot spring fluid* }}+0.55 \times \delta^{18} \mathrm{O}_{\text {lake water* }}=0.45 \times(-3.21)+0.55 \times 6.73=$ 2.06\% (VSMOW),

where $*$ stands for actual $\delta^{18} \mathrm{O}$ values of hot spring fluid and lake water (Table 2).

As the hydrothermal vent temperatures suggest rather low-temperature precipitation processes $\left[\mathrm{T}_{\text {hydrothermal fluid }}=70-100^{\circ} \mathrm{C}\right.$ in 1970's (Fontes et al., 1980) and $37-98.6^{\circ} \mathrm{C}$ now (Table 1)], we used the equation of Kim and O'Neil $(1997)\left[10^{3} \ln \alpha=18.03\left(10^{3} / \mathrm{T}\right)-32.42\right]$ for calcite-water O-isotope fractionation in the calculation of precipitation temperatures. A fractionation increase of $10^{3} \ln \alpha_{(\mathrm{Mg} \text {-calcite - H2O) }}$ is accounted for using a shift of $0.17 \%$ per mol $\% \mathrm{MgCO}_{3}$ (cf. Jimenez-Lopez et al., 2004). Additionally, we performed the same calculations using the fluid compositions measured in the 1970's (Fontes et al., 1980) (Table 2).

Our calculations show that the most internal chimney layer (\#1) precipitated at lower temperature than the most external layer (\#6) (Table 2). The decreasing temperature of carbonate precipitation towards the central zone of the chimney may be explained with precipitation of carbonate consecutive layers towards the centre of the chimney conduit (trend of conduit sealing) and cessation of hydrothermal activity: decrease of hydrothermal fluid temperature (i.e., decrease in temperature of mixed fluid if we assume that the lake water temperature had not changed).

The measured $\delta^{13} \mathrm{C}$ values of 2 and $4.17 \%$ VPDB (Table 2), assuming that the low-Mg calcite would precipitate in equilibrium with a $\delta^{13} \mathrm{C}_{\mathrm{CO} 2}$ of -6.7 to $-6.0 \%$ VPDB at the calculated temperatures (Table 2), would indicate more or less the same carbon source for the internal and external part of the chimney. Moreover, our calculated isotope composition of $\mathrm{CO}_{2}$ is theoretically in accordance with the $\delta^{13} \mathrm{C}_{\mathrm{TIC}}$ of $+0.63 \%$, which was measured in Lake Abhé waters in 1975 (Fontes et al., 1980).

$\mathrm{Sr}$ geochemically follows $\mathrm{Ca}$, and $\mathrm{Sr}$ isotopes provide additional constraints on the mixing of source components that formed the carbonate chimneys. ${ }^{87} \mathrm{Sr} /{ }^{86} \mathrm{Sr}$ data reinforce the finding 
that the carbonate chimneys precipitated from a mixture of spring fluid and Lake Abhé water. As can be seen on Figure 7, Sr isotope data indicate $45-42 \%$ spring fluid contribution in zones \#1 to \#3 and 10-3.6\% for zones \#4 to \#6, broadly consistent with the results of the REE mixing model (Fig. $6 \mathrm{C}$ ). The relatively low ${ }^{87} \mathrm{Sr} /{ }^{86} \mathrm{Sr}=0.7038$ observed in the spring fluid indicates that $\mathrm{Sr}$ is predominantly leached from the underlying volcanic rocks, most likely from the Stratoid Series (Deniel et al., 1994), which dominate the bedrock in the lake region. Lake Abhé is recharged by the Awash River, characterized by ${ }^{87} \mathrm{Sr} /{ }^{86} \mathrm{Sr}$ values of 0.7068 0.7072 (Bretzler et al., 2011). Therefore, the elevated ${ }^{87} \mathrm{Sr} /{ }^{86} \mathrm{Sr}$ in the Lake Abhé water reflects the contribution from the Awash River. $\mathrm{Nd}$ and $\mathrm{Pb}$ isotopes, on the other hand, show little variation in the six zones compared to $\mathrm{Sr}$ isotopes (Table 2). The only exception is the $\mathrm{Pb}$ isotope composition of the external zone \#6, which shows less radiogenic ${ }^{206} \mathrm{~Pb} /{ }^{204} \mathrm{~Pb}$ coupled with slightly elevated ${ }^{207} \mathrm{~Pb} /{ }^{204} \mathrm{~Pb}$. The external zone has been exposed to the atmosphere for years so the shift in the $\mathrm{Pb}$ isotopes can be simply due to atmospheric contamination by recent anthropogenic $\mathrm{Pb}$. As can be seen in Figure 10, the carbonates exhibit lower $\varepsilon \mathrm{Nd}$ data compared to the Stratoid Series, one of the end-members controlling the $\mathrm{Sr}$ isotope composition of the hot spring fluid. Similarly, the $\mathrm{Pb}$ isotopic composition of the carbonates is also slightly different than the Stratoid Series. We could not determine the $\mathrm{Nd}$ and $\mathrm{Pb}$ isotopic compositions of the lake water and spring fluid due to very low concentrations. Given the elevated ${ }^{87} \mathrm{Sr} /{ }^{86} \mathrm{Sr}$ in the lake water we can assume that the lake water will carry $\mathrm{Nd}$ with lower $\varepsilon N d$ compared to Stratoid Series and the spring fluid. Therefore, the offset to lower $\varepsilon \mathrm{Nd}$ and higher ${ }^{87} \mathrm{Sr} /{ }^{86} \mathrm{Sr}$ in the carbonate chimney is consistent with mixing of lake water and spring fluid.

The $\delta^{44 / 40} \mathrm{Ca}$ value of pure calcite from the chimney interior (\#1; Table 2) can be readily accounted for by precipitation from fluid closely resembling modern hot spring fluid, which is slightly higher in $\delta^{44 / 40} \mathrm{Ca}$ relative to the pure calcite chimney interior. Experimental data reveal that $\mathrm{Ca}$-isotope fractionation during inorganic calcite precipitation is modulated by precipitation rate and temperature, producing calcite that is depleted in ${ }^{44} \mathrm{Ca}$ relative to parent fluids (Tang et al., 2008). In contrast to internal pure calcite, the $\delta^{44 / 40} \mathrm{Ca}$ of the external low$\mathrm{Mg}$ calcite layer \#6 is $0.8 \%$ higher than that of the hot spring fluid (Table 2). This excludes its formation solely from recent hot spring fluid, even if it provided 50 times more Ca than lake water. An additional Ca source with higher $\delta^{44 / 40} \mathrm{Ca}$ is required for the formation of the external low-Mg calcite layer, the most likely candidate being recent lake water (Table 2). The preliminary, but extremely high $\delta^{44 / 40} \mathrm{Ca}$ value of lake water likely reflects disequilibrium Ca-carbonate precipitation and accompanying ${ }^{44} \mathrm{Ca}$ enrichment of residual lake water, 
possibly as the result of multiple lake drying and Ca-reservoir depletion events. The high $\delta^{44 / 40} \mathrm{Ca}$ value of the external low-Mg calcite layer thus supports the assumption of lake desiccation during the formation of the outermost low-Mg calcite layer. Finally, it should be noted that not much is known regarding potential differences in Ca-isotope fractionation between the formation of pure calcite (internal part) and low-Mg calcite (external layer). Nevertheless, the mineralogical robustness of Ca-isotope fractionation might be indirectly inferred by the similarity of $\mathrm{Ca}$-isotope fractionation during microbially-induced precipitation of Mg-rich dolomite (Krause et al., 2012) and the formation of pure aragonite in scleractinian corals (Böhm et al., 2006).

\subsection{U-Th constraints on the age of chimney formation}

Age dating of the chimney is complicated by the very low ${ }^{230} \mathrm{Th}$ values (and low ${ }^{230} \mathrm{Th} /{ }^{232} \mathrm{Th}$ ratios). In addition, the anomalously high ${ }^{232} \mathrm{Th}$ and $\mathrm{Th}_{\text {tot. }}$ concentrations in the low-Mg calcite layers $(\# \# 4,6$; Tables 1,2) indicate that a substantial amount of inherited ${ }^{230} \mathrm{Th}$ may have been incorporated during carbonate formation. The higher contents of terrigenous elements ( $\mathrm{Al}, \mathrm{Nb}, \mathrm{Ta}, \mathrm{Hf}, \mathrm{Y}$ and $\mathrm{Sc}$ ) in these low-Mg calcite layers relative to the calcite layers $(\# \# 1,2,3,5)$ (Table 1) are clearly consistent with a significant terrigenous component being incorporated during carbonate precipitation. Despite the potential difficulty in dating these carbonate chimneys, the fact that ${ }^{230} \mathrm{Th} /{ }^{232} \mathrm{Th}$ activity ratios for all samples are similar and do not exhibit any correlation with ${ }^{238} \mathrm{U} /{ }^{232} \mathrm{Th}$ activity ratios suggest that the chimneys were formed relatively recently. This is further supported by the fact that the ${ }^{234} \mathrm{U} /{ }^{238} \mathrm{U}$ activity ratios of the carbonate samples are very similar to the lake water value. Therefore, we are confident that the isochron age calculated for the studied samples $(0.28 \pm$ $0.54 \mathrm{kyr})$ truly reflects the mean age of carbonate formation. Interestingly, palaeoenvironmental data available for the Lake Abhé suggest that it has dessicated twice during the last $\sim 5000$ yrs B.P., at ca. 3-4000 yrs B.P. and at present (Gasse, 1977). This provides support for a recent age of formation for the studied carbonate chimneys.

\section{Summary}

Giant carbonate chimneys at the shores of a desiccating hypersaline and alkaline lake from a continental rift setting (Lake Abhé, Afar Rift) were formed in a lake water body with a higher-than-modern water level. Mineralogy and geochemistry of the chimneys suggest they 
are a result of rapid carbonate precipitation during the interaction of hydrothermal fluids with lake water. The chimneys' internal texture of alternating calcite and low-Mg calcite + silica concentric layers implies they grew under dynamic geochemical conditions. C-O-isotope data indicate that the chimney carbonates precipitated at temperatures of $\sim 14-22^{\circ} \mathrm{C}$, with a carbon source consisting of atmospheric $\mathrm{CO}_{2}$ (equilibrated with alkaline lake water). Deviation of lake water O-isotope data (compared to 1970 's data) and variability between $\delta^{18} \mathrm{O}$-values of different parts of the carbonate chimney supports carbonate precipitation from mixed (hydrothermal and lake water) fluids with variable evaporative stages of the lake. Pronounced positive $\mathrm{Ce}$ anomalies and HREE enrichment in lake water may be accounted for by stablilization of carbonato- Ce and HREE aqueous complexes at high alkalinity, and their perserverance in all chimney layers thus clearly indicate important contributions from alkaline lake water. Mixing calculations based on Sr concentrations and Sr-isotope data indicate a hydrothermal fluid contribution of $\sim 45 \%$ for chimney interior, which decreases to $\sim 4 \%$ for the external chimney layer. $\mathrm{Sr}$ in the hydrothermal fluids is predominantly leached from the underlying volcanic rocks, whereas the lake's Sr budget is dominated mostly by riverine runoff. Supporting the Sr-isotope results, Ca-isotope data show that only the internal calcite layers drew $\mathrm{Ca}$ almost entirely from hydrothermal fluid. The most external low-Mg calcite layer received $\mathrm{Ca}$ predominantly sourced from lake water, consistent with the Sr-isotope data. The still preliminary but exceptionally high $\delta^{44 / 40} \mathrm{Ca}$ value of recent lake water might reflect a progressive enrichment of ${ }^{44} \mathrm{Ca}$ through multiple lake drying and Ca-reservoir depletion events. Thus the high $\delta^{44 / 40} \mathrm{Ca}$ of the most external low-Mg calcite layer, combined with $\delta^{18} \mathrm{O}$ data, support the assumption of lake desiccation during the precipitation of this layer. The calculated low formation temperatures and U-Th age dating suggest the chimneys were formed relatively recently under declining hydrothermal vent activity, no earlier than $0.82 \mathrm{kyr}$ $\mathrm{BP}(0.28 \pm 0.54)$.

\section{Acknowledgements}

This research was supported by the European Community as an Integrating Activity "Support of Public and Industrial Research Using Ion Beam Technology (SPIRIT)" (EC contract \#227012) and by a Marie Curie Intra European Fellowship (7th European Community Framework Programme; grant \#253182, IsoBAB) to V. M. Dekov, and an NSERC PDF grant to S. V. Lalonde. N. Lemaitre and the technical staff at the Pôle 
Spectrométrie Océan (IFREMER, Brest) are warmly thanked for their help during sample preparation and analyses with MC-ICP-MS and SF-ICP-MS. Two anonymous reviewers and the handling editor, J. Fein, are thanked for their comments and professional handling of the manuscript.

\section{References}

Amini, M., Eisenhauer, A., Böhm, F., Fietzke, J., Bach, W., Garbe-Schönberg, D., Rosner, M., Bock, B., Lackschewitz, K.S., Hauff, F., 2008. Calcium isotope $\left(\delta^{44 / 40} \mathrm{Ca}\right)$ fractionation along hydrothermal pathways, Logatchev field (Mid-Atlantic Ridge, 14² $5^{\prime} \mathrm{N}$ ). Geochim. Cosmochim. Acta 72, 4107-4122.

Barberi, F., Varet, J., 1977. Volcanism of Afar: Small-scale plate tectonics implications. Geol. Soc. Am. Bull. $88,1251-1266$.

Barrat, J.-A., Keller, F., Amossé, J., Taylor, R.N., Nesbitt, R.W., Hirata, T., 1996. Determination of rare earth elements in sixteen silicate reference samples by ICP-MS after Tm addition and ion exchange separation. Geostand. Newslett. 20, 133-139.

Barrat, J.-A., Boulègue, J., Tiercelin, J.J., Lesourd, M., 2000. Strontium isotopes and rare-earth element geochemistry of hydrothermal carbonate deposits from Lake Tanganyika, East Africa. Geochim. Cosmochim. Acta 64, 287-298.

Bastow, I.D., Keir, D., 2011. The protracted development of the continent-ocean transition in Afar. Nature Geoscience 4, 248-250.

Bau, M., 1991. Rare-earth element mobility during hydrothermal and metamorphic fluid-rock interaction and the significance of the oxidation state of europium. Chem. Geol. 93, 219-230.

Bau, M., Dulski, P., 1996. Distribution of yttrium and rare-earth elements in the Penge and Kuruman ironformations, Transvaal Supergroup, South Africa. Precambrian Res. 79, 37-55.

Bau, M., Koschinsky, A., Dulski, P., Hein, J., 1996. Comparison of the partitioning behaviours of yttrium, rare earth elements, and titanium between hydrogenetic marine ferromanganese crusts and seawater. Geochim. Cosmochim. Acta 60, 1709-1725.

Bayon, G., Barrat, J.-A., Etoubleau, J., Benoit, M., Bollinger, C., Révillon, S., 2009a. Determination of rare earth elements, Sc, Y, Zr, Ba, Hf and Th in geological samples by ICP-MS after Tm addition and alkaline fusion. Geostand. Geoanal. Res. 33, 51-62.

Bayon, G., Henderson, G.M., Bohn, M., 2009b. U-Th stratigraphy of a cold seep carbonate crust. Chem. Geol. 260, 47-56.

Bayon, G., Birot, D., Bollinger, C., Barrat, J.-A., 2011. Multi-elemental analyses of trace metals in seawater by ICP-SFMS after Tm addition and iron co-precipitation. Geostand. Geoanal. Res. 35, 145-153.

Bayon, G., Dupré, S., Ponzevera, E., Etoubleau, J., Chéron, S., Pierre, C., Mascle, J., Boetius, A., de Lange, G., 2013. Formation of carbonate chimneys in the Mediterranean Sea linked to deep-water oxygen depletion. Nature Geosci. 6, 755-760. 
Benson, L., 1994. Carbonate deposition, Pyramid Lake Subbasin, Nevada: 1. Sequence of formation and elevational distribution of carbonate deposits (Tufas). Palaeogeogr. Palaeocl. Palaeoecol. 109, 55-87.

Beyene, A., Abdelsalam, M.G., 2005. Tectonics of the Afar Depression: A review and synthesis. J. Afr. Earth Sci. 41, 41-59.

Bischoff, J.L., Stine, S., Rosenbauer, R.J., Fitzpatrick, J.A., Stafford Jr., T.W., 1993. Ikaite precipitation by mixing of shoreline springs and lake water, Mono Lake, California, USA. Geochim. Cosmochim. Acta 57, 3855-3865.

Bottinga, Y., 1969. Calculated fractionation factors for carbon and hydrogen isotope exchange in the system calcite - carbon dioxide- graphite - methane - hydrogen - water vapor. Geochim. Cosmochim. Acta 33, 49-64.

Böhm, F., Gussone, N., Eisenhauer, A., Dullo, W.-C., Reynaud, S., Paytan, A., 2006. Calcium isotope fractionation in modern scleractinian corals. Geochim. Cosmochim. Acta 70, 4452-4462.

Branchu, P., Bergonzini, L., Delvaux, D., De Batist, M., Golubev, V., Benedetti, M., Klerkx, J., 2005. Tectonic, climatic and hydrothermal control on sedimentation and water chemistry of northern Lake Malawi (Nyasa), Tanzania. J. Afr. Earth Sci. 43, 433-446.

Bretzler, A., Osenbruck, K., Gloaguen, R., Ruprecht, J.S., Kebede, S., Stadler, S., 2011. Groundwater origin and flow dynamics in active rift systems - a multi-isotope approach in the Main Ethiopian Rift. J. Hydrol. 402, 274-289.

Cheng, H., Adkins, J., Edwards, R.L., Boyle, E.A., 2000. U-Th dating of deep-sea corals. Geochim. Cosmochim. Acta 64, 2401-2416.

Corliss, J.B., Dymond, J., Gordon, L.I., Edmond, J.M., Von Herzen, R.P., Ballard, R.D., Green, K., Williams, D., Bainbridge, A., Crane, K., Van Andell, T.H., 1979. Submarine thermal springs on the Galapagos Rift. Science 203, 1073-1083.

Crane, K., Hecker, V., Golubev, V., 1991. Hydrothermal vents in Lake Baikal. Nature 350, 281.

Darling, W.G., Bath, A.H., Gibson, J.J., Rozanski, K., 2005. Isotopes in water. In: Leng, M.J. (Ed.), Isotopes in Palaeoenvironmental Research. Springer, Dordrecht, pp. 1-66.

D’Amore, F., Giusti, D., Abdallah, A., 1998. Geochemistry of the high-salinity geothermal field of Asal, Republic of Djibouti, Africa. Geothermics 27, 197-210.

De Chabalier, J.-B., Avouac, J.-P., 1994. Kinematics of the Asal Rift (Djibouti) determined from the deformation of Fieale Volcano. Science 265, 1677-1681.

Demange, J., Stieltjes, L., 1975. Géologie de la région sud-ouest du T.F.A.I. (région lac Abhé-lac Asal). Bull. B.R.G.M. 2, 83-119.

Demange, J., Di Paola, G.-M., Lavigne, J.-J., Lopoukhine, M., Stieltjes, L., 1971. Etude géothermique du Territoire Français des Afars et des Issas, avril 1971, Paris, Rapport B.R.G.M.

Deniel, C., Vidal, P., Coulon, C., Vellutini, P.-J., Piguet, P., 1994. Temporal evolution of mantle sources during continental rifting: The volcanism of Djibouti (Afar). J. Geophys. Res. 99 B2, 2853-2869.

Dettman, D., Palacios-Fest, M.R., Nkotagu, H.H., Cohen, A.S., 2005. Paleolimnological investigations of anthropogenic environmental change in Lake Tanganyika: VII. Carbonate isotope geochemistry as a record of riverine runoff. J. Paleolimnol. 34, 93-105.

Ebinger, C., Casey, M., 2001. Continental breakup in magmatic provinces: An Ethiopian example. Geology 29, 527-530. 
Edwards, R.L., Chen, J.H., Wasserburg, G.R., 1986. ${ }^{238} \mathrm{U}_{-}{ }^{234} \mathrm{U}_{-}{ }^{230} \mathrm{Th}^{2}{ }^{232} \mathrm{Th}$ systematics and the precise measurement of time over the past 500,000 years. Earth Planet. Sci. Lett. 81, 175-192.

Fontes, J.C., Pouchan, R., 1975. Les cheminées du lac Abhé (T.F.A.I.): Stations hydroclimatiques de l'Holocène. C.R. Acad. Sci. Paris 280, 383-386.

Fontes, J.C., Pouchon, P., Saliege, J.F., Zuppi, G.M., 1980. Environmental isotope study of groundwater systems in the Republic of Djibouti. In: Arid Zone Hydrology: Investigations with Isotope Techniques, Proceedings of an Advisory Group Meeting, IAEA, Vienna, 337-226.

Ford, T.D., Pedley, H.M., 1996. A review of tufa and travertine deposits of the world. Earth Sci. Rev. 41, 117175.

Fouillac, A.M., Fouillac, C., Cesbron, F., Pillard, F., Legendre, O., 1989. Water-rock interaction between basalt and high-salinity fluids in the Asal Rift, Republic of Djibouti. Chem. Geol. 76, 271-289.

Freslon, N., Bayon, G., Birot, D., Bollinger, C., Barrat, J.-A., 2011. Determination of rare earth elements and other trace elements $(\mathrm{Y}, \mathrm{Mn}, \mathrm{Co}, \mathrm{Cr})$ in seawater using $\mathrm{Tm}$ addition and $\mathrm{Mg}(\mathrm{OH})_{2}$ co-precipitation. Talanta $85,582-587$.

Gasse, F., 1977. Evolution of Lake Abhé (Ethiopia and TFAI), from 70,000 b.p. Nature 265, 42-45.

Gasse, F., Street, F.A., 1978. Late Quaternary lake-level fluctuations and environments of the northern Rift Valley and Afar region (Ethiopia and Djibouti). Palaeogeogr. Palaeocl. Palaeoecol. 24, 279-325.

Gasse, F., Dagain, J., Mazet, G., Richard, O., Fournier, M., 1987. Carte géologique de la République de Djibouit au 1:100000, Dikhil. ISERT, ORSTOM, Notice explicative, 85 pp.

German, C.R., Von Damm, K.L., 2004. Hydrothermal processes. In: Turekian, K.K., Holland, H.D. (Eds.), Treatise on Geochemistry, 6. In: Elderfield, H. (Ed.), The Oceans and Marine Geochemistry. Elsevier, Oxford, pp. 181-222.

Goldsmith, J.R., Graf, D.L., Heard, H.C., 1969. Lattice constants of the calcium-magnesium carbonates. Am. Mineral. 46, 453-457.

Granina, L.Z., Klerkx, J., Callender, E., Leermakers, M., Golobokova, L.P., 2007. Bottom sediments and pore waters near a hydrothermal vent in Lake Baikal (Frolikha Bay). Russ. Geol. Geophys. 48, 237-246.

Hannington, M., Jamieson, J., Monecke, T., Petersen, S., Beaulieu, S., 2011. The abundance of seafloor massive sulfide deposits. Geology 39, 1155-1158.

Hayward, N.J., Ebinger, C.J., 1996. Variations in the along-axis segmentation of the Afar Rift system. Tectonics $15,244-257$.

Herrmann, F., Grambole, D., 1995. The new Rossendorf nuclear microprobe. Nucl. Instrum. Meth. B 104, $26-30$. Herzig, P.M., Becker, K.P., Stoffers, P., Bäcker, H., Blum, N., 1988. Hydrothermal silica chimney fields in the Galapagos Spreading Center. Earth Planet. Sci. Lett. 89, 261-272.

Heuser, A., Eisenhauer, A., Gussone, N., Bock, B., Hansen, B.T., Nägler, T.F., 2002. Measurement of calcium isotopes $\left(\delta^{44} \mathrm{Ca}\right)$ using a multicollector TIMS technique. Int. J. Mass Spectrom. 220, 387-399.

Jimenez-Lopez, C., Romanek, C.S., Huertas, F.J., Ohmoto, H., Caballero, E., 2004. Oxygen isotope fractionation in synthetic magnesian calcite. Geochim. Cosmochim. Acta 68, 3367-3377.

Johannesson, K.H., Lyons, W.B., Bird, D.A., 1994. Rare earth element concentrations and speciation in alkaline lakes from the western U.S.A. Geophys. Res. Lett. 21, 773-776. 
Jones, B., Renaut, R.W., 1996. Skeletal crystals of calcite and trona from hot-spring deposits in Kenya and New Zealand. J. Sediment. Res. 66, 265-274.

Kamenov, G.D., Perfit, M.R., Mueller, P.A., Jonasson, I.R., 2008. Controls on magmatism in an island arc environment: study of lavas and sub-arc xenoliths from the Tabar-Lihir-Tanga-Feni island chain, Papua New Guinea. Contrib. Mineral. Petr. 155, 635-656.

Kim, S.-T., O’Neil, J.R., 1997. Equilibrium and non-equilibrium oxygen isotope effects in synthetic carbonates. Geochim. Cosmochim. Acta 61, 3461-3475.

Klinkhammer, G.P., Elderfield, H., Edmond, J.M., Mitra, A., 1994. Geochemical implications of rare earth element patterns in hydrothermal fluids from mid-ocean ridges. Geochim. Cosmochim. Acta 58, 5105-5113.

Krause, S., Liebetrau, V., Gorb, S., Sánchez-Román, M., McKenzie, J.A., Treude, T., 2012. Microbial nucleation of Mg-rich dolomite in exopolymeric substances under anoxic modern seawater salinity: New insight into an old enigma. Geology 40, 587-590.

Linhoff, B.S., Bennett, P.C., Puntsag, T., Gerel, O., 2011. Geochemical evolution of uraniferous soda lakes in Eastern Mongolia. Env. Earth Sciences 62, 171-183.

Ludwig, K.R., 2009. Isoplot v. 3.71: A geochronological toolkit for Microsoft Excel. Berkeley, California, Berkeley Geochronology Center Special Publication.

Lumsden, D.N., 1979. Error in X-ray diffraction estimates of dolomite in carbonate rocks: causes and cures. AAPG Bull. 63, 488.

Möller, P., Bau, M., 1993. Rare-earth patterns with positive cerium anomaly in alkaline waters from Lake Van, Turkey. Earth Planet. Sci. Lett. 117, 671-676.

Moucha, R., Forte, A.M., 2011. Changes in African topography driven by mantle convection. Nature Geoscience 4, 707-712.

Müller, G., Förstner, U., 1973. Recent iron ore formation in Lake Malawi, Africa. Miner. Deposita 8, 278-290.

Pflumio, C., Boulègue, J., Tiercelin, J.-J., 1994. Hydrothermal activity in the Northern Tanganyika Rift, East Africa. Chem. Geol. 116, 85-109.

Pourret, O., Davranche, M., Gruau, G., Dia, A., 2007. Competition between humic acid and carbonates for rare earth elements complexation. Journal of Colloid And Interface Science 305, 25-31.

Rango, T., Petrini, R., Stenni, B., Bianchini, G., Slejko, F., Beccaluva, L., Ayenew, T., 2010. The dynamics of central Main Ethiopian Rift waters: Evidence from $\delta \mathrm{D}, \delta^{18} \mathrm{O}$ and ${ }^{87} \mathrm{Sr} /{ }^{86} \mathrm{Sr}$ ratios. Appl. Geochem. 25, 18601871.

Razack, M., Aboubaker, M., Jalludin, M., 2013. Numerical modeling of the Dikhil basaltic aquifer, south west Djibouti, Horn of Africa. J. Groundwater Res. 2, 91-102.

Renaut, R.W., Owen, R.B., Jones, B., Tiercelin, J.-J., Tarits, C., Ego, J.K., Konhauser, K.O., 2013. Impact of lake-level changes on the formation of thermogene travertine in continental rifts: Evidence from Lake Bogoria, Kenya Rift Valley. Sedimentology 60, 428-468.

Rongemaille, E., Bayon, G., Pierre, C., Bollinger, C., Chu, N.C., Foquet, Y., Riboulot, V., Voisset, M., 2011. Rare earth elements in cold seep carbonates from the Niger delta. Chem. Geol. 286, 196-206.

Rosen, M.R., Arehart, G.B., Lico, M.S., 2004. Exceptionally fast growth rate of $<100$-yr-old tufa, Big Soda Lake, Nevada: Implications for using tufa as a paleoclimate proxy. Geology 32, 409-412. 
Ryan, J.G., Langmuir, C.H., 1987. The systematics of lithium abundances in young volcanic rocks. Geochim. Cosmochim. Acta 51, 1727-1741.

Simpson, H.J., Trier, R.M., Olsen, C.R., Hammond, D.E., Ege, A., Miller, L., Melack, J.M., 1980. Fallout plutonium in an alkaline, saline lake. Science 207, 1071-1073.

Skulan, J., DePaolo, D.J., Owens, T.L., 1997. Biological control on calcium isotopic abundances in the global calcium cycle. Geochim. Cosmochim. Acta 61, 2505-2510.

Spiess, F.N., Macdonald, K.C., Atwater, T., Ballard, R., Carranza, A., Cordoba, D., Cox, C., Diaz Garcia, V.M., Francheteau, J., Guerrero, J., Hawkins, J., Haymon, R., Hessler, R., Juteau, T., Kastner, M., Larson, R., Luyendyk, B., Macdougall, J.D., Miller, S., Normark, W., Orcutt, J., Rangin, C., 1980. East Pacific Rise: hot springs and geophysical experiments. Science 207, 1421-1433.

Tang, J., Dietzel, M., Böhm, F., Köhler, S.J., Eisenhauer, A., 2008. $\mathrm{Sr}^{2+} / \mathrm{Ca}^{2+}$ and ${ }^{44} \mathrm{Ca} /{ }^{40} \mathrm{Ca}$ fractionation during inorganic calcite formation: II. Ca isotopes. Geochim. Cosmochim. Acta 72, 3733-3745.

Taylor, S.R., McLennan, S.M., 1985. The Continental Crust: Its Composition and Evolution. Blackwell, Oxford, $311 \mathrm{p}$.

Teng, F.-Z., McDonough, W.F., Rudnick, R.L., Dalpé, C., Tomascak, P.B., Chappell, B.W., Gao, S., 2004. Lithium isotopic composition and concentration of the upper continental crust. Geochim. Cosmochim. Acta $68,4167-4178$.

Tiercelin, J.-J., Chorowicz, J., Bellon, H., Richert, J.P., Mwanbene, J.T., Walgenwitz, F., 1988. East African Rift System: Offset, age and tectonic significance of the Tanganyika-Rukwa-Malawi intracontinental transcurrent fault zone. Tectonophysics 148, 241-252.

Tiercelin, J.-J., Thouin, C., Kalala, T., Mondeguer, A., 1989. Discovery of sublacustrine hydrothermal activity and associated massive sulfides and hydrocarbons in the north Tanganyika trough, East African Rift. Geology 17, 1053-1056.

Tiercelin, J.-J., Pflumio, C., Castrec, M., Boulègue, J., Gente, P., Rolet, J., Coussement, C., Stetter, K.O., Huber, R., Buku, S., Mifundu, W., 1993. Hydrothermal vents in Lake Tanganyika, East African Rift system. Geology 21, 499-502.

Wasserburg, G.J., DePaolo, D.J., 1979. Models of Earth structure inferred from neodymium and strontium isotopic abundances. Proceed. Nat. Acad. Sci. 76, 3594-3598.

Whittaker, E.J.W., Muntus, R., 1970. Ionic radii for use in geochemistry. Geochim. Cosmochim. Acta 34, $945-$ 956.

Wright, T.J., Ebinger, C., Biggs, J., Ayele, A., Yirgu, G., Keir, D., Stork, A., 2006. Magma-maintained rift segmentation at continental rupture in the 2005 Afar dyking episode. Nature 442, 291-294.

Zeng, Z.G., Chen, D.G., Yin, X.B., Wang, X.Y., Zhang, G.L., Wang, X.M., 2009a. Elemental and isotopic compositions of the hydrothermal sulfide on the East Pacific Rise near $13^{\circ} \mathrm{N}$. Sci. China Ser. D doi: 10.1007/s11430-010-0013-3.

Zeng, Z.G., Yu, S.X., Yin, X.B., Wang, X.Y., Zhang, G.L., Wang, X.M., Chen, D.G., 2009b. Element enrichment and U-series isotopic characteristics of the hydrothermal sulfides at Jade site in the Okinawa Trough. Sci. China Ser. D 52, 913-924. 
Figure captions

Fig. 1. Inactive carbonate chimneys from the desiccating bottom of Lake Abhé: (A) chain of coalescent chimneys (the tallest is $\sim 35 \mathrm{~m}$; Lake Abhé in blue behind the chimneys); (B) single chimneys ( $\sim 15 \mathrm{~m})$; (C) surface of a carbonate chimney (close up).

Fig. 2. (A) Digital elevation model (DEM) of the Afar Rift system with the location of Lake Abhé. Vertical color scale $=$ altitude in $\mathrm{m}$; long-dashed red lines $=$ tectonic escarpments; short-dashed red lines $=$ Red Sea and Gulf of Aden spreading centers; bold red lines = magmatic segments (Wright et al., 2012); rectangle encloses the area enlarged in B. (B) DEM of the Afar Rift showing the extensional fault network in the Lake Abhé area: a range of horsts and grabens and the dormant Dama Ale volcano. Red star = studied chimney; red lines $=$ faults.

Fig. 3. (A) Spire of the studied inactive carbonate chimney (note the botryoidal surface crust) with the position of cross-section $\left(\mathrm{B}_{1}-\mathrm{B}_{2}\right)$ shown at Figure $3 \mathrm{~B}$; (B) cross-section of the studied chimney spire $\left(\mathrm{B}_{1}-\mathrm{B}_{2}\right.$ at Figure $3 \mathrm{~A}$ ) with sample locations (samples \#DJ-19-07-1 to \#DJ-19-07-6): red dotted lines encompass sampled white layers, black dashed lines encompass sampled brownish-white layers; (C) SEM photomicrograph (SEI) of calcite skeletal crystals from the most internal part (\#DJ-19-07-1) of the chimney; (D) internal structure of the calcite crystals (thin section; optical microscope, transmitted plane polarized light).

Fig. 4. PIXE and RBS maps of the textures within the carbonate chimney (\#DJ-19-07). Scans in: $\mathrm{Ca} K$ lines (A), Sr $K$ lines (B), O from RBS (C), Mn $K$ lines (D), Ba $L$ lines (E), and Fe $K$ lines (F). The values of the color scale bars are an approximation of the concentration in wt.\%. Note, the homogenous Ca-Sr-O-zone is a calcite layer (\#DJ-19-07-5), whereas the Ba and Fe rich layer is the external chimney crust composed of low-Mg calcite (\#DJ-19-07-6).

Fig. 5. X-ray maps of skeletal calcite crystals (polished section; \#DJ-19-07-5): (A) X-ray scan in $\mathrm{Ca} K_{\alpha}$; (B) X-ray scan in $\mathrm{Mg} K_{\alpha}$; (C) X-ray scan in Si $K_{\alpha}$. Color scales (right-hand side), elemental concentrations in wt.\%. 
Fig. 6. (A) Post-Archean Australian Shale (PAAS)-normalized (Taylor and McLennan, 1985) REE distribution patterns of the studied carbonate chimney and associated fluids. Black lines represent carbonate chimney samples \#\#1-6 and gray lines represent associated fluids: solid line, lake water; dotted line, hot spring fluid; dashed line, cold spring fluid. (B) Plot of $\mathrm{Ce} / \mathrm{Ce}$ * $\left[2 \mathrm{Ce}_{\mathrm{SN}} /\left(\operatorname{Pr}_{\mathrm{SN}}+\mathrm{La}_{\mathrm{SN}}\right)\right]$ vs $\operatorname{Pr} / \operatorname{Pr}^{*}\left[2 \operatorname{Pr}_{\mathrm{SN}} /\left(\mathrm{Ce}_{\mathrm{SN}}+\mathrm{Nd}_{\mathrm{SN}}\right)\right]$ demonstrating true positive Ce anomalies in Lake Abhé carbonates and lake water. Yellow squares = carbonate chimneys of Lake Abhé (this work); black squares $=$ carbonate chimneys of Lake Tanganyika, East African Rift (Barrat et al., 2000); red circles = Lake Abhé hot spring fluid $;$ orange circles $=$ Lake Abhé cold spring fluid; turquoise circles $=$ Lake Abhé water (this work). Crossed lines at $(1,1)$ represent PAAS, and the lightest grey shaded area represents no $\mathrm{Ce}$ anomaly or false $\mathrm{Ce}$ anomalies that may stem from anomalies in La (c.f. Bau and Dulski, 1996).

Fig. 7. Sr isotopes for carbonate chimney, hot spring fluid, and Lake Abhé water. Mixing between hot spring fluid and lake water can explain the isotope composition of the chimney, for more discussion see the text. Percents above bars show the relative amount of hot spring fluid $\mathrm{Sr}$ in the carbonate. Numbers 1 to 6 represent the sample locations shown on Figure 3.

Fig. 8. Rosholt isochron diagram for the Lake Abhé carbonate chimney samples. The dashed line represents the equiline. The thick line corresponds to the best-fit for $\left({ }^{230} \mathrm{Th} /{ }^{232} \mathrm{Th}\right) \mathrm{vs}$. $\left({ }^{238} \mathrm{U} /{ }^{232} \mathrm{Th}\right.$ ) ratios of chimney samples (Table 2), whose slope provides a mean formation age using a conventional isochron approach, assuming that all the samples had precipitated at the same time.

Fig. 9. Stable $\mathrm{H}$ and $\mathrm{O}$ isotope composition of Lake Abhé water and hot spring fluid (this study) compared with published data and plotted against the local (LMWL) and the global meteoric water line (GMWL). Additionally, a local evaporation line (LEL) established for the East African Rift area and evaporation trends (gray arrows) in a shallow lake system are plotted according to Rango et al. (2010) and Darling et al. (2005), respectively.

Fig. 10. $\mathrm{Sr}, \mathrm{Nd}$ and $\mathrm{Pb}$ isotopes for carbonate chimney compared to lavas of the 3-1 Ma-old Stratoid Series. The Series are composed of tholeiitic basalts with interbeded rhyolites and are representative of the basement lithology in the Lake Abhé area (Deniel et al., 1994). 


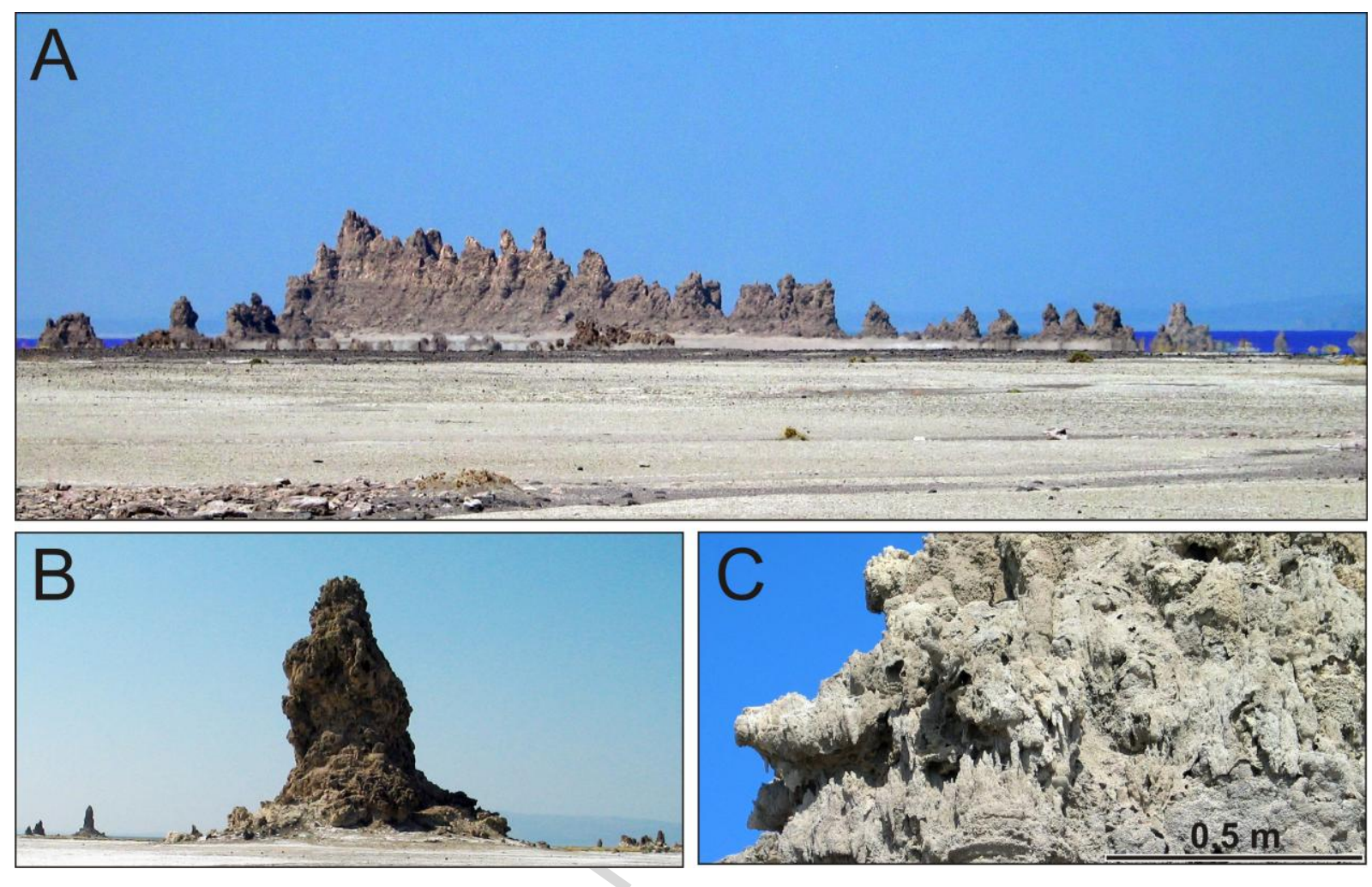

Figure 1 


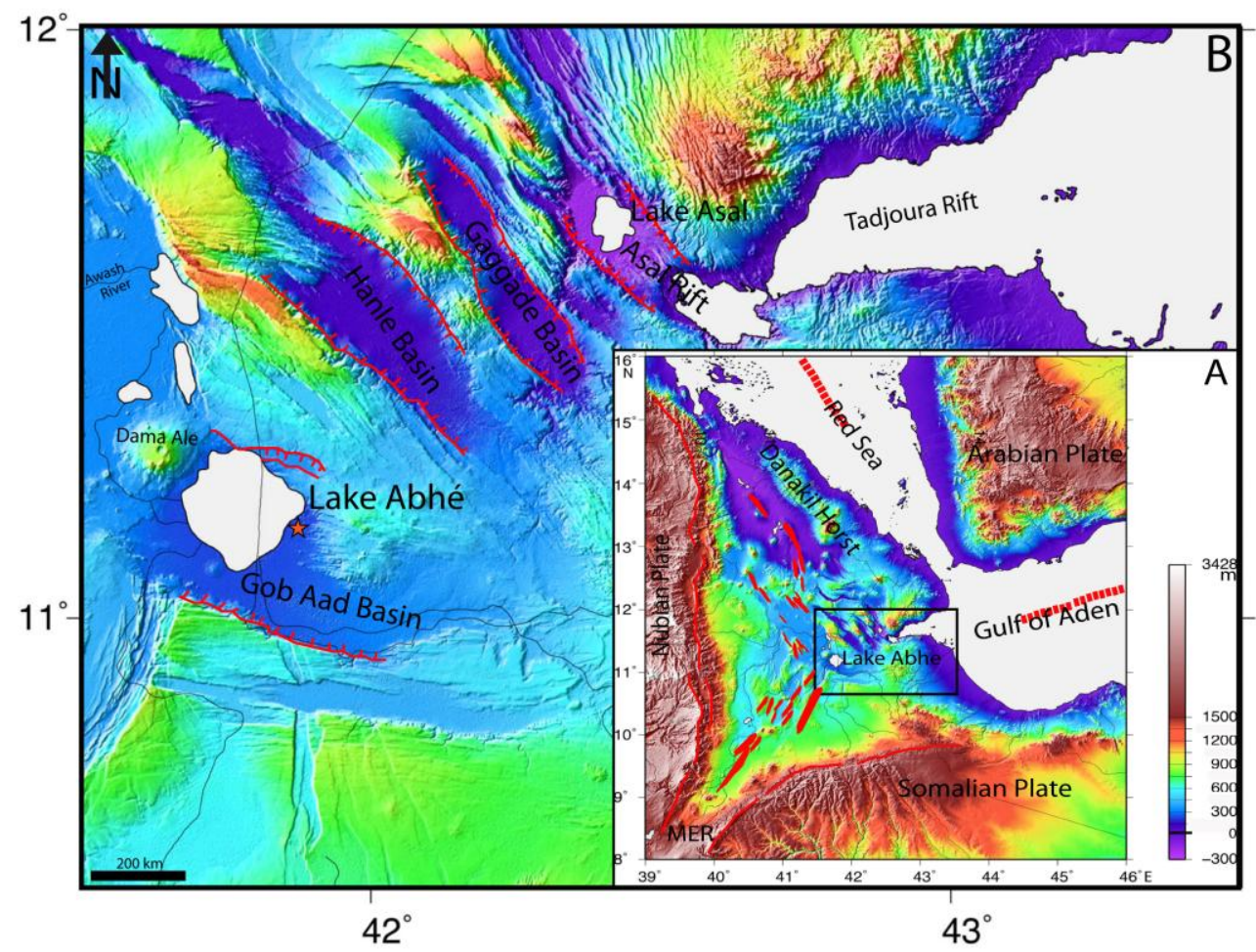

Figure 2 

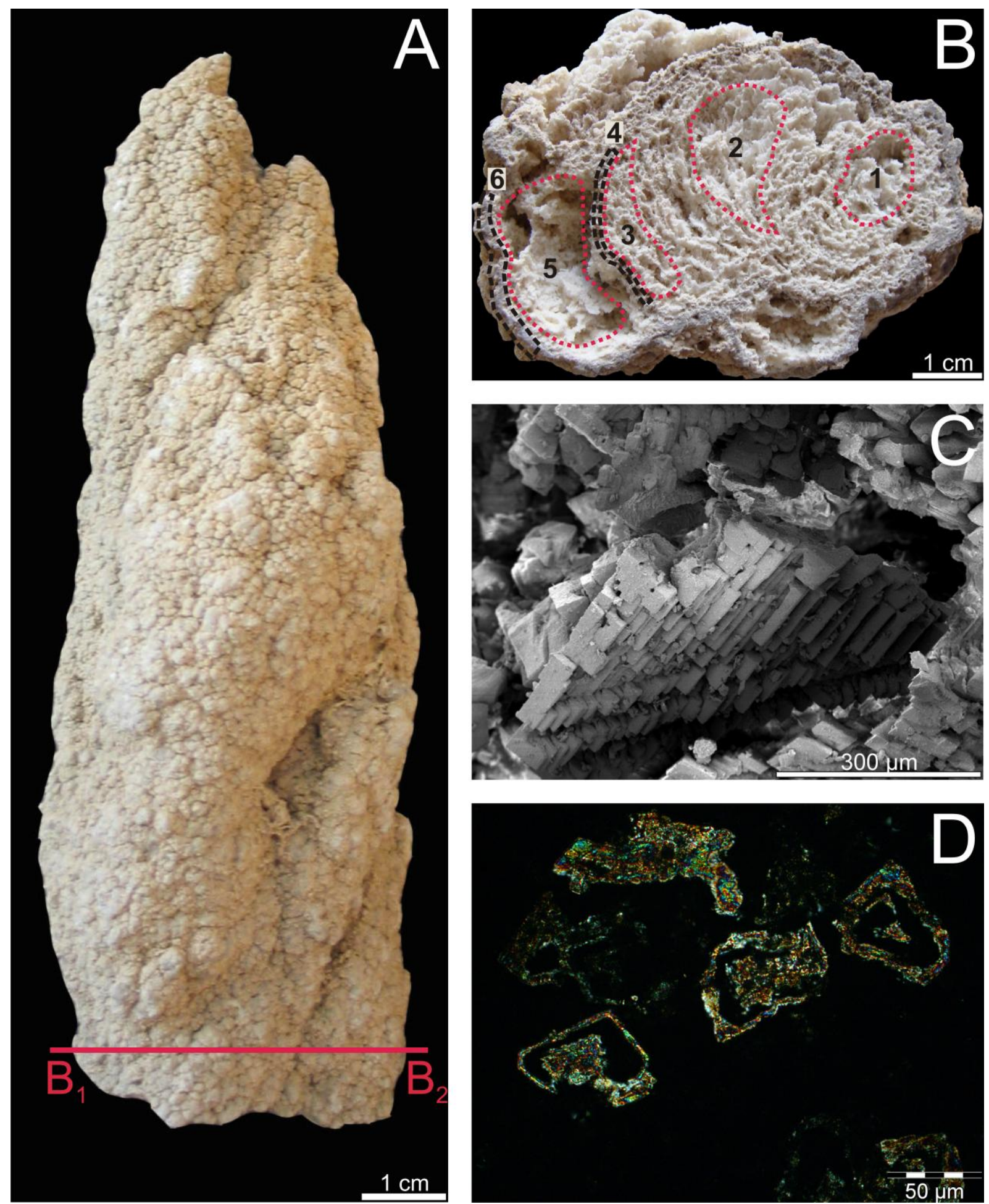

Figure 3 

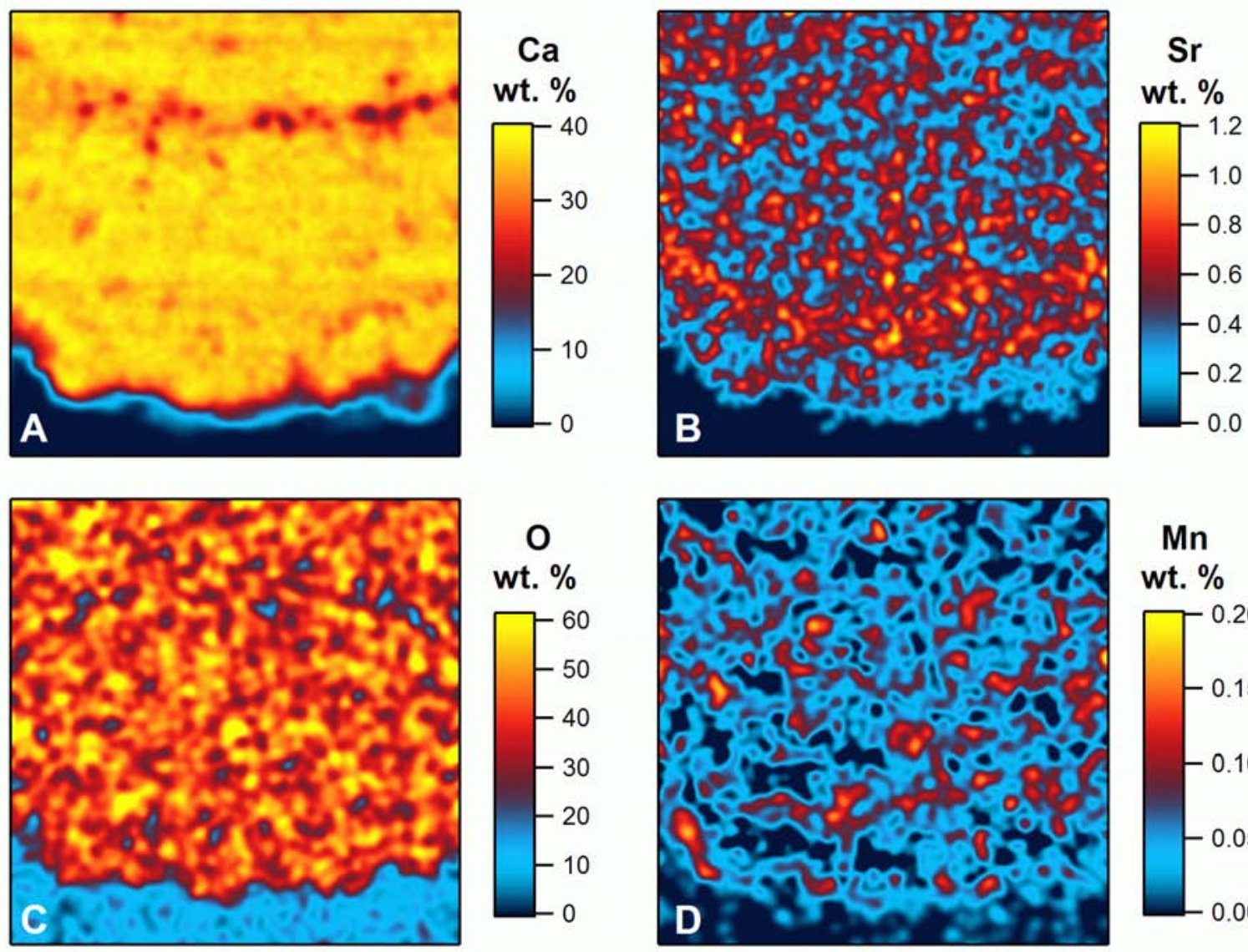

\section{Mn}

wt. $\%$
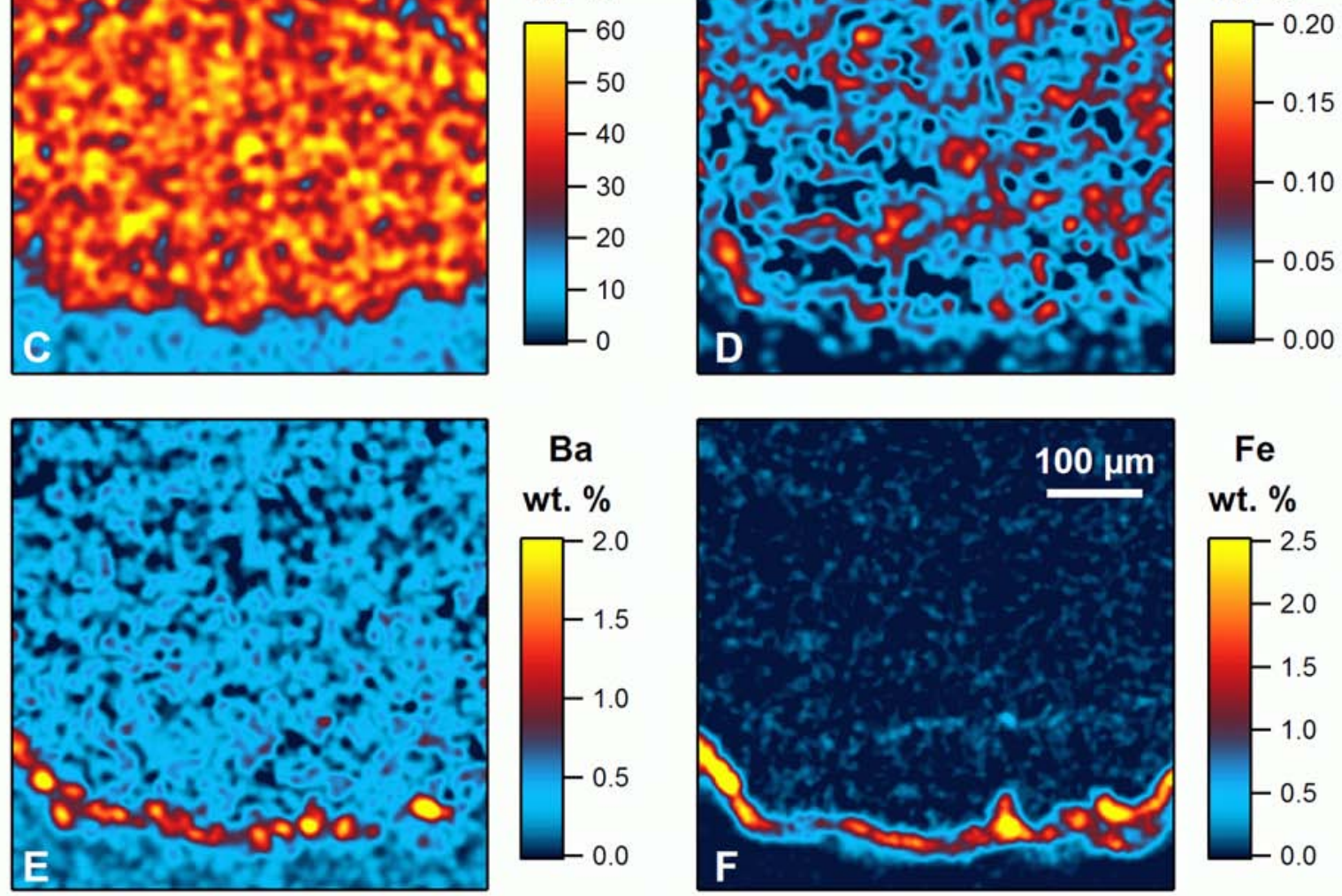

Figure 4 


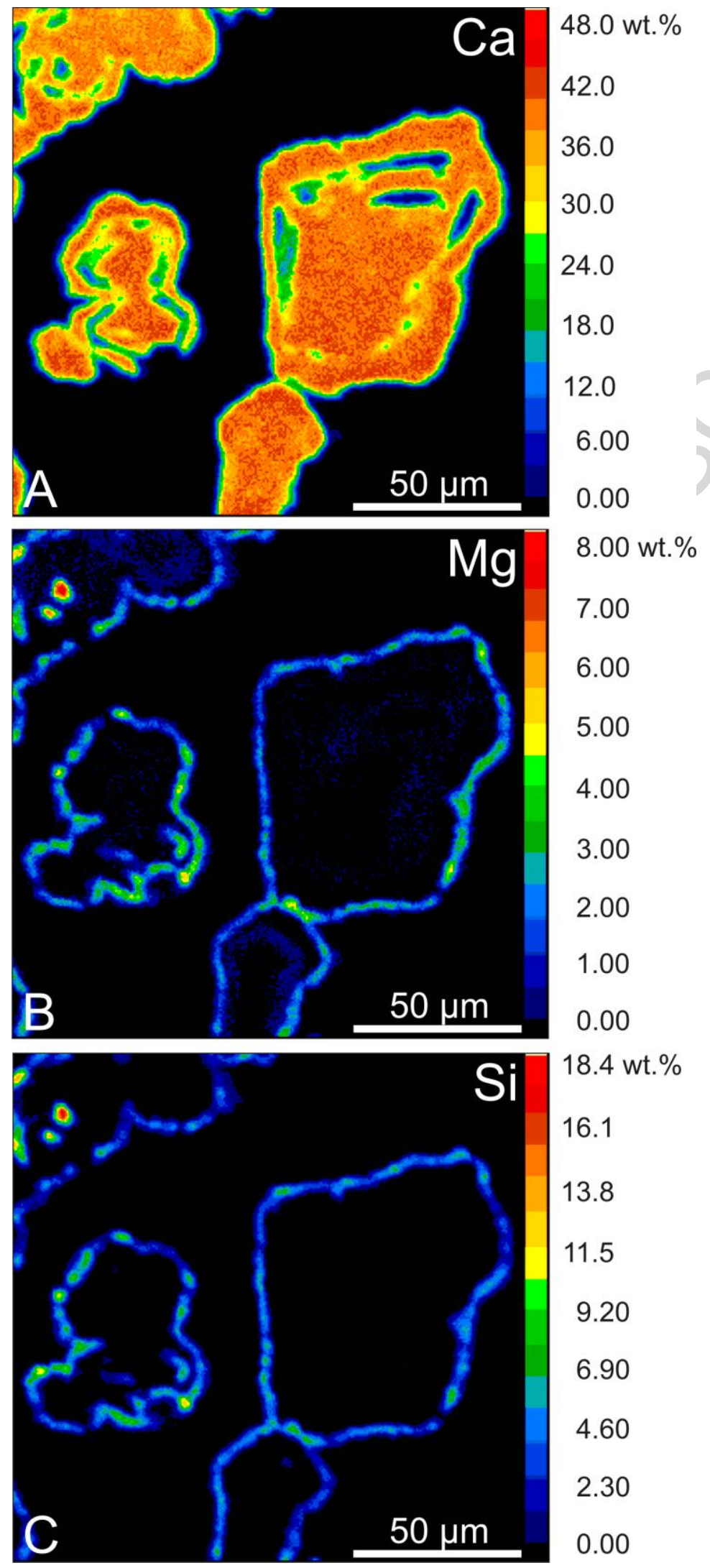

Figure 5 


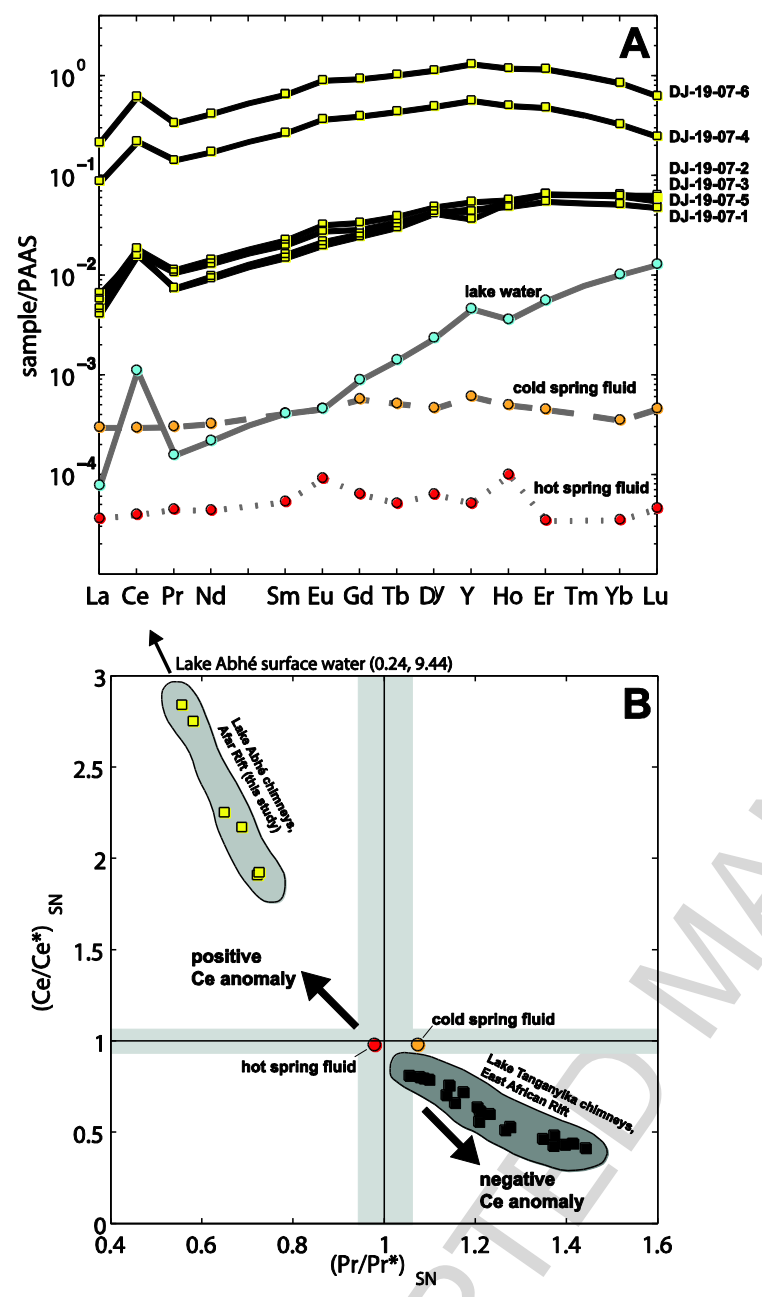

Figure 6 


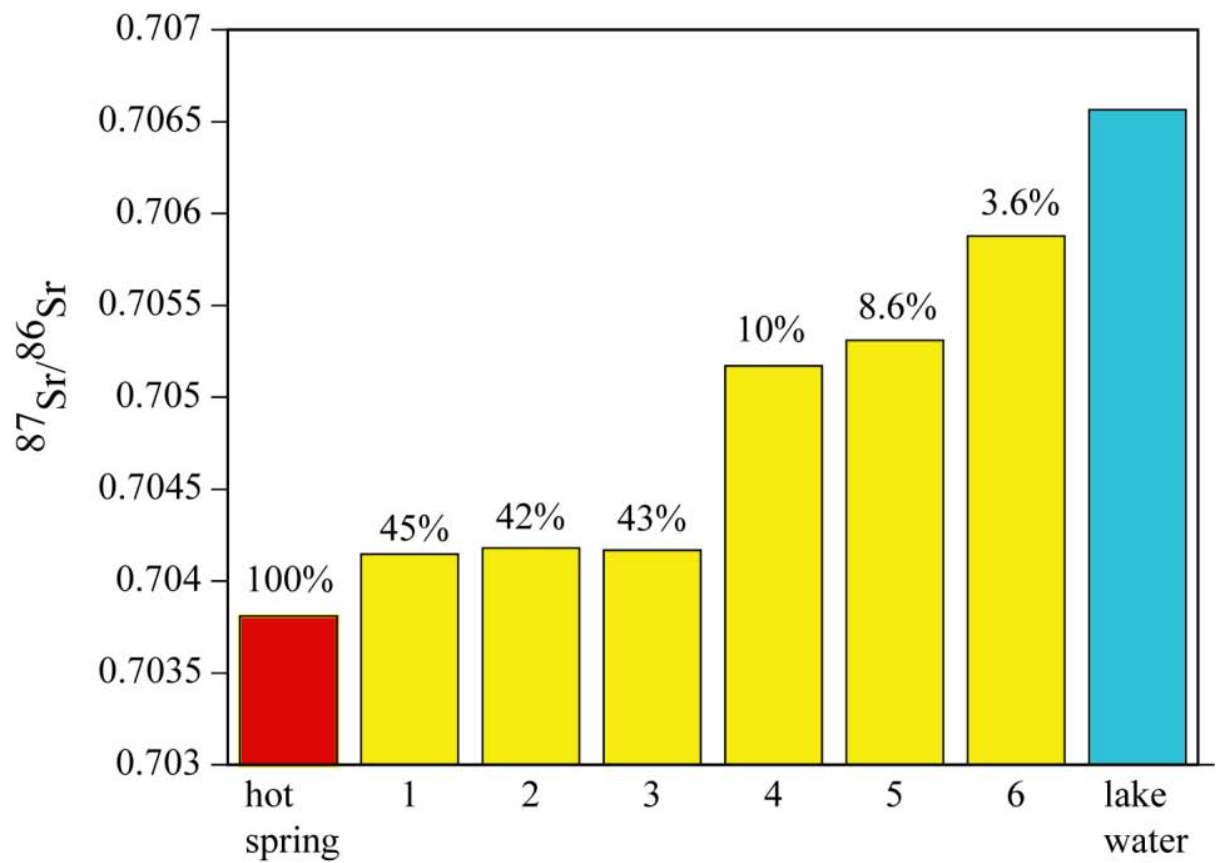

Figure 7 


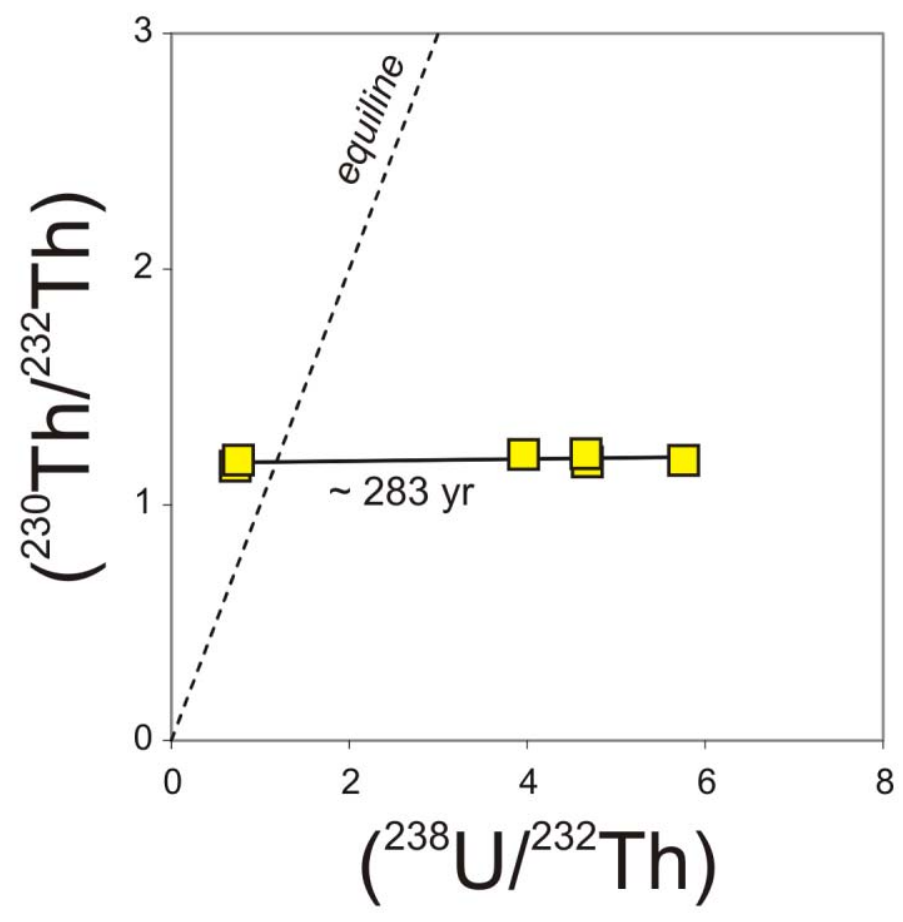

Figure 8 


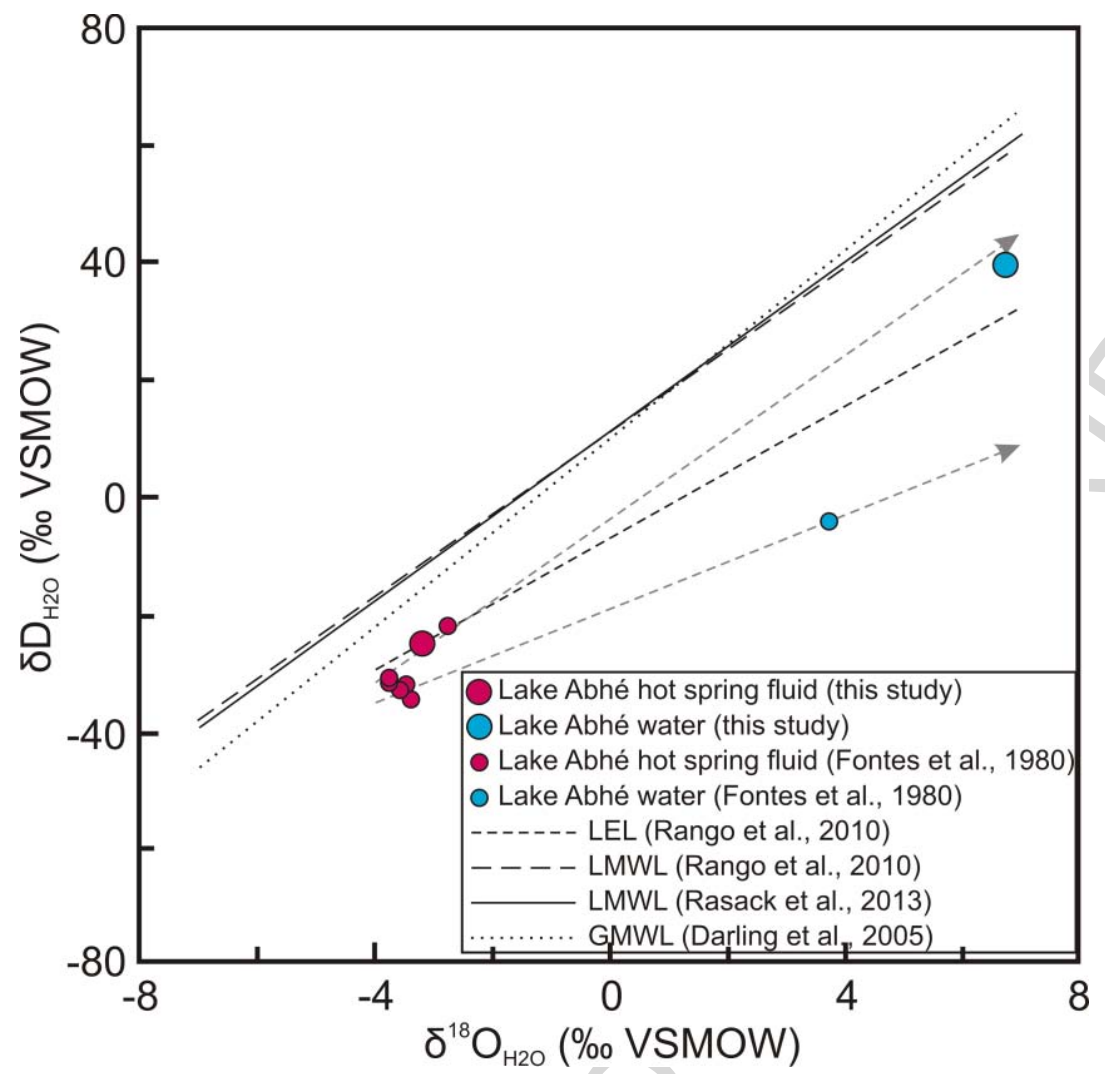

Figure 9 


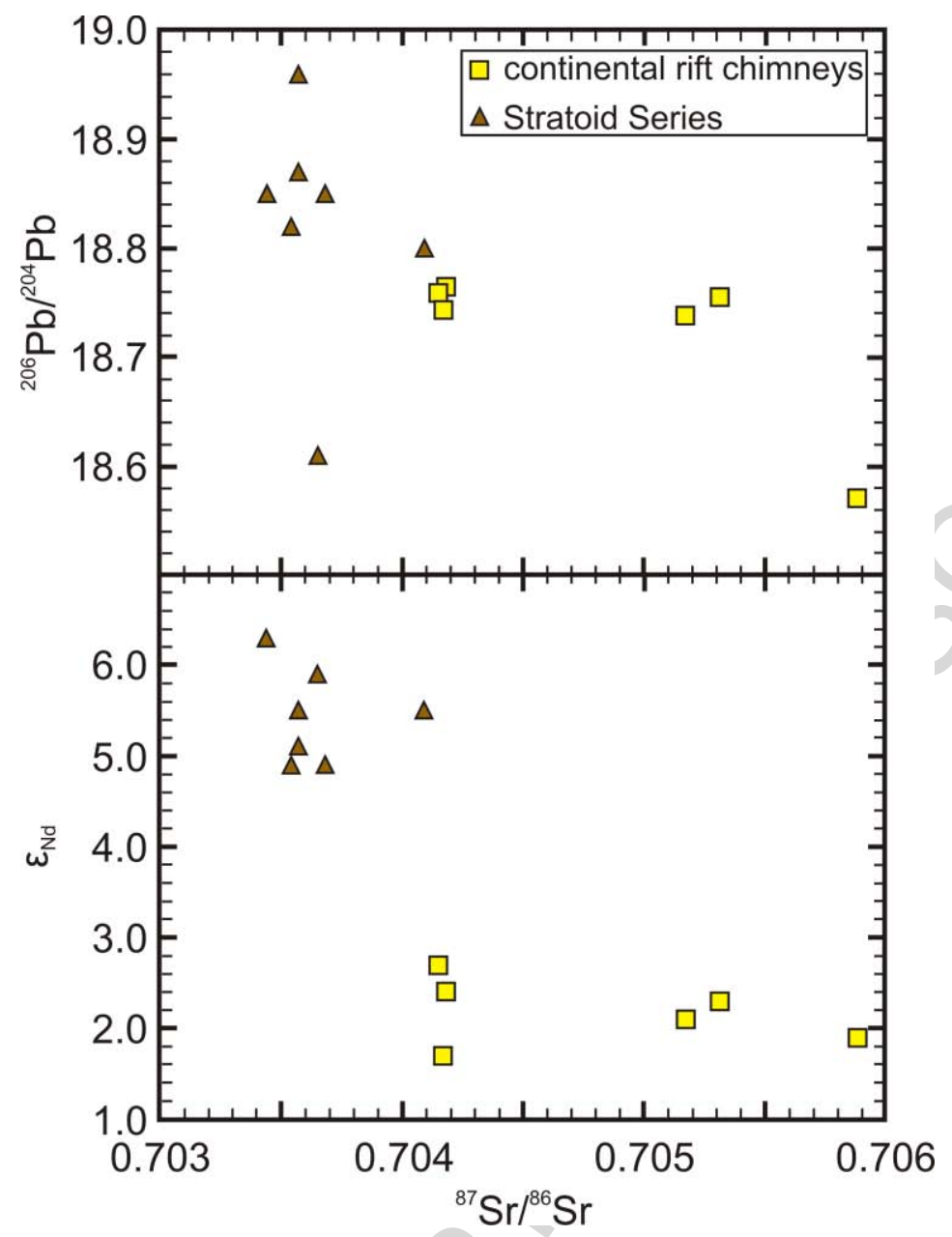

Figure 10 
Table 1

Temperature, $\mathrm{pH}$ and chemical composition of continental rift chimney, spring fluids and lake water (Afar Rift).

\begin{tabular}{|c|c|c|c|c|c|c|c|c|c|}
\hline $\begin{array}{l}\text { Sample \# } \\
\text { Element }\end{array}$ & J-19-07-1 & DJ-19-07-2 & DJ-19-07-3 & DJ-19-07-4 & DJ-19-07-5 & DJ-19-07-6 & Hot spring fluid & Cold spring fluid & Lake Abhé water \\
\hline $\mathrm{T},{ }^{\circ} \mathrm{C}$ & - & & - & - & - & & 98.6 & 37 & 28 \\
\hline $\mathrm{pH}\left(20^{\circ} \mathrm{C}, 1 \mathrm{~atm}\right)$ & - & & - & - & - & & 7.9 & 8.8 & 10.0 \\
\hline $\mathrm{Ca}, \mathrm{ppm}$ & 390562 & - & - & - & - & 342447 & 229 & - & 4 \\
\hline $\mathrm{Mg}$ & 2296 & - & - & - & - & 25792 & 0.13 & - & 1.03 \\
\hline $\mathrm{Si}$ & 1012 & - & - & - & - & 26871 & $\nabla$ & - & - \\
\hline $\mathrm{Al}$ & 43 & 86 & 62 & 107 & 25 & 757 & - & - & - \\
\hline $\mathrm{Fe}$ & 241 & 283 & 224 & 186 & 95 & 532 & 0.008 & - & 0.103 \\
\hline $\mathrm{K}$ & - & - & - & - & - & & 36 & - & 225 \\
\hline $\mathrm{Na}$ & - & - & - & - & - & & 1001 & - & 13351 \\
\hline As & 1.49 & 1.25 & 1.02 & 1.39 & 1.34 & 1.57 & 0.328 & - & 0.002 \\
\hline $\mathrm{Ba}$ & 105 & 154 & 138 & 621 & 109 & 1105 & 0.072 & - & 0.012 \\
\hline $\mathrm{Cu}$ & 1.84 & 1.95 & 1.63 & 2.24 & 1.02 & 3.41 & 0.0039 & - & 0.0018 \\
\hline $\mathrm{Li}$ & 9.49 & 12.42 & 12.11 & 15.22 & 6.33 & 9.41 & - & - & - \\
\hline $\mathrm{Mn}$ & 24.15 & 19.64 & 13.48 & 242.8 & 11.28 & 569.4 & 0.0092 & - & 0.0032 \\
\hline $\mathrm{Sr}$ & 2854 & 3225 & 3005 & 4138 & 1982 & 4713 & 0.238 & - & 0.027 \\
\hline $\mathrm{Ti}$ & 6.84 & 12.25 & 7.16 & 7.88 & 2.75 & 55.75 & - & - & - \\
\hline $\mathrm{Co}, \mathrm{ppb}$ & 699 & 668 & 507 & 455 & 337 & 884 & 0.33 & - & 0.03 \\
\hline $\mathrm{Cr}$ & 2637 & 2008 & 1670 & 1777 & $\longrightarrow$ & 7459 & 0.12 & - & 0.3 \\
\hline Cs & 14.5 & 11.2 & 10.2 & 22.6 & 4.0 & 59.5 & - & - & - \\
\hline $\mathrm{Ge}$ & 36.5 & 39.9 & 36.3 & 51.1 & 13.8 & 98.8 & - & - & - \\
\hline Hf & 15.0 & 11.4 & $<\mathrm{DL}^{\mathrm{a}}$ & 22.1 & $<\mathrm{DL}$ & 83.2 & - & - & - \\
\hline Mo & 16.6 & 13.8 & 10.3 & 13.8 & 3.5 & 62.7 & - & - & - \\
\hline $\mathrm{Nb}$ & 61.2 & 87.5 & 60.3 & 85.4 & 75.0 & 379.1 & - & - & - \\
\hline $\mathrm{Ni}$ & 9248 & 9622 & 8787 & 6175 & 4922 & 5367 & 0.4 & - & 0.68 \\
\hline $\mathrm{Pb}$ & 1273 & 1189 & 594 & 1518 & 413 & 1874 & 0.12 & - & 0.09 \\
\hline $\mathrm{Rb}$ & 161 & 179 & 145 & 399 & 67.1 & 1246 & - & - & - \\
\hline $\mathrm{Sb}$ & 58.4 & 70.0 & 59.8 & 93.5 & 28.1 & 110.2 & - & - & - \\
\hline $\mathrm{Sc}$ & 188 & 173 & 145 & 161 & 367 & 487 & - & - & - \\
\hline $\mathrm{Se}$ & 21.6 & 7.4 & 12.3 & 42.8 & $<\mathrm{DL}$ & 75.8 & - & - & - \\
\hline $\mathrm{Sn}$ & 88.4 & 114.8 & 145.0 & 300.3 & 52.4 & 282.4 & - & - & - \\
\hline $\mathrm{Ta}$ & 14.6 & 11.6 & 4.1 & 8.3 & 36.3 & 28.1 & - & - & - \\
\hline Th & 339 & 573 & 527 & 1609 & 243 & 5070 & - & 0.011 & 0.847 \\
\hline $\mathrm{Tl}$ & 7.4 & 7.6 & 3.9 & 3.7 & 2.0 & 8.3 & - & - & - \\
\hline $\mathrm{U}$ & 663 & 553 & 632 & 349 & 459 & 965 & 113 & 6.724 & 1.530 \\
\hline V & 1611 & 2037 & 1787 & 7126 & 711 & 16139 & 237 & - & 0.33 \\
\hline $\mathrm{Y}$ & 1262 & 1001 & 1191 & 15472 & 1488 & 35970 & 0.014 & 0.166 & 1.255 \\
\hline $\mathrm{Zn}$ & 2783 & 1742 & 852 & 1203 & 467 & 2292 & 0.52 & - & 1.28 \\
\hline $\mathrm{Zr}$ & 464 & 364 & 265 & 374 & 67.4 & 1746 & - & - & - \\
\hline $\mathrm{La}$ & 255 & 179 & 159 & 3381 & 224 & 8260 & 0.014 & 0.115 & 0.030 \\
\hline $\mathrm{Ce}$ & 1325 & 1362 & 1282 & 17749 & 1491 & 49861 & 0.032 & 0.237 & 0.891 \\
\hline $\operatorname{Pr}$ & 95.2 & 65.2 & 66.7 & 1272 & 101 & 3010 & 0.004 & 0.027 & 0.014 \\
\hline $\mathrm{Nd}$ & 447 & 318 & 335 & 5909 & 492 & 14335 & 0.015 & 0.111 & 0.075 \\
\hline $\mathrm{Sm}$ & 113 & 84.0 & 90.7 & 1512 & 127 & 3687 & 0.003 & 0.023 & 0.023 \\
\hline $\mathrm{Eu}$ & 30.5 & 21.8 & 23.8 & 402 & 35.2 & 987 & 0.001 & 0.005 & 0.005 \\
\hline $\mathrm{Gd}$ & 136 & 115 & 123 & 1867 & 159 & 4434 & 0.003 & 0.027 & 0.042 \\
\hline $\mathrm{Tb}$ & 26.8 & 23.4 & 25.6 & 343 & 30.5 & 802 & 0.0004 & 0.004 & 0.011 \\
\hline Dy & 201 & 198 & 207 & 2345 & 231 & 5392 & 0.003 & 0.022 & 0.111 \\
\hline Ho & 49.0 & 53.9 & 55.2 & 507 & 57.2 & 1194 & 0.001 & 0.005 & 0.036 \\
\hline $\mathrm{Er}$ & 159 & 186 & 189 & 1394 & 188 & 3390 & 0.001 & 0.013 & 0.161 \\
\hline $\mathrm{Tm}$ & - & - & - & - & - & - & - & - & - \\
\hline $\mathrm{Yb}$ & 147 & 181 & 185 & 934 & 179 & 2426 & 0.001 & 0.010 & 0.290 \\
\hline $\mathrm{Lu}$ & 20.7 & 27.7 & 26.6 & 107 & 24.2 & 273 & 0.0002 & 0.002 & 0.056 \\
\hline$\Sigma$ REE & 3006 & 2815 & 2768 & 37721 & 3339 & 98050 & 0.079 & 0.601 & 1.745 \\
\hline$\left(\mathrm{Ce} / \mathrm{Ce}^{*}\right)^{\mathrm{b}}$ & 1.91 & 2.84 & 2.75 & 1.92 & 2.17 & 2.25 & 0.98 & 0.98 & 9.44 \\
\hline$\left(\mathrm{Eu} / \mathrm{Eu}^{*}\right)^{\mathrm{c}}$ & 1.12 & 1.00 & 1.00 & 1.13 & 1.15 & 1.16 & 1.74 & 1.03 & 0.62 \\
\hline $\mathrm{La}_{\mathrm{SN} /} \mathrm{Lu}_{\mathrm{SN}}$ & 0.14 & 0.07 & 0.07 & 0.36 & 0.10 & 0.34 & 0.79 & 0.65 & 0.01 \\
\hline
\end{tabular}


Table 2

Isotopic compositions of samples from the continental rift chimney, spring fluids and lake water (Afar Rift).

\begin{tabular}{|c|c|c|c|c|c|c|c|c|c|c|c|c|c|c|c|c|c|c|}
\hline Sample \# & $\begin{array}{l}\delta \mathrm{D} \\
(\% \text { VSMOW) }\end{array}$ & $\begin{array}{l}\delta^{13} \mathrm{C} \\
(\% \text { VPDB })\end{array}$ & $\begin{array}{l}\delta^{13} \mathrm{C}_{\mathrm{CO} 2}{ }^{\mathrm{a}} \\
(\% \text { VPDB) }\end{array}$ & $\begin{array}{l}\delta^{18} \mathrm{O} \\
(\%)\end{array}$ & $\begin{array}{l}\delta^{18} \mathrm{O}_{\mathrm{H} 2 \mathrm{O}}{ }^{\mathrm{b}} \\
(\% \mathrm{o})\end{array}$ & \multirow[t]{2}{*}{$\begin{array}{l}\mathrm{T}^{\mathrm{b}} \\
\left({ }^{\circ} \mathrm{C}\right)\end{array}$} & $\begin{array}{l}\delta^{18} \mathrm{O}_{\mathrm{H} 2 \mathrm{O}}{ }^{\mathrm{c}} \\
(\% \mathbf{0})\end{array}$ & $\begin{array}{l}\mathrm{T}^{\mathrm{c}} \\
\left({ }^{\circ} \mathrm{C}\right)\end{array}$ & $\begin{array}{l}\Delta^{18} \mathrm{O}_{\mathrm{Mg}} \\
(\% \mathbf{0})\end{array}$ & \multicolumn{2}{|c|}{$\begin{array}{l}\delta^{44 / 40} \mathrm{Ca} \\
(\%)\end{array}$} & $2 \sigma$ & \multicolumn{2}{|c|}{${ }^{87} \mathrm{Sr} /{ }^{86} \mathrm{Sr}$} & $2 \sigma$ & \multicolumn{2}{|c|}{${ }^{143} \mathrm{Nd} /{ }^{144} \mathrm{Nd} \quad 2 \sigma$} & $\varepsilon-\mathrm{Nd}$ \\
\hline DJ-19-07-1 & & 2.00 & -6.7 & $1.54^{\mathrm{d}}$ & 2.06 & & 0.495 & 7 & 0 & 0.6 & & 0.06 & 0.70 & 148 & 0.000010 & 0.512774 & 0.000013 & 2.7 \\
\hline DJ-19-07-2 & & - & - & - & - & - & - & - & & - & & - & 0.70 & 179 & 0.000007 & 0.512760 & 0.000010 & 2.4 \\
\hline DJ-19-07-4 & & - & - & - & - & - & - & & & - & & - & 0.70 & 171 & 0.000011 & 0.512744 & 0.000008 & 2.1 \\
\hline DJ-19-07-5 & & - & - & - & - & - & - & & - & - & & - & 0.70 & 312 & 0.000011 & 0.512755 & 0.000016 & 2.3 \\
\hline DJ-19-07-6 & & 4.17 & -6.0 & $4.73^{\mathrm{d}}$ & 6.37 & 22 & 3.47 & 9 & 0.7 & 1.7 & & 0.02 & 0.70 & 879 & 0.000010 & 0.512737 & 0.000007 & 1.9 \\
\hline Lake Abhé water & 39.58 & - & - & $6.73^{\mathrm{e}}$ & - & - & - & - & - & 3.4 & & 0.08 & 0.70 & 565 & 0.000028 & - & - & - \\
\hline Sample \# & ${ }^{206} \mathrm{~Pb} /{ }^{204} \mathrm{~Pb}$ & ${ }^{207} \mathrm{~Pb} /{ }^{204} \mathrm{~Pb}$ & ${ }^{208} \mathrm{~Pb} /{ }^{204} \mathrm{~Pb}$ & ${ }^{208} \mathrm{~Pb} /{ }^{206} \mathrm{P}$ & ${ }^{207} \mathrm{~Pb}$ & $\mathrm{~Pb}$ & $\begin{array}{l}{ }^{232} \mathrm{Th} \\
(\mathrm{ppb})\end{array}$ & $2 \sigma\left(^{23}\right.$ & $\left.{ }^{0} \mathrm{Th} /{ }^{232} \mathrm{Th}\right){ }^{1}$ & & $2 \sigma$ & $\begin{array}{l}{ }^{238} \mathrm{U} \\
(\mathrm{ppb})\end{array}$ & & $2 \sigma$ & $\left({ }^{234} U{ }^{238} U\right)^{f}$ & $2 \sigma$ & $\left({ }^{238} \mathrm{U} /^{232} \mathrm{Th}\right)^{\mathrm{f}}$ & $2 \sigma$ \\
\hline DJ-19-07-1 & 18.759 & 15.585 & 38.474 & 2.05098 & 0.830 & 832 & 294 & 1 & 1.1 & & 0.01 & 553 & & 0.7 & 1.338 & 0.002 & 5.76 & 0.02 \\
\hline DJ-19-07-2 & 18.765 & 15.592 & 38.493 & 2.05127 & 0.830 & 856 & 352 & 2 & 1.2 & & 0.01 & 456 & & 0.6 & 1.331 & 0.002 & 3.96 & 0.02 \\
\hline DJ-19-07-3 & 18.744 & 15.593 & 38.520 & 2.05516 & 0.831 & 929 & 352 & 3 & 1.2 & & 0.02 & 538 & & 0.7 & 1.332 & 0.002 & 4.66 & 0.04 \\
\hline DJ-19-07-5 & 18.756 & 15.593 & 38.528 & 2.05418 & 0.831 & 384 & 329 & 1 & 1.1 & & 0.02 & 504 & & 0.6 & 1.334 & 0.002 & 4.68 & 0.02 \\
\hline DJ-19-07-6 & 18.571 & 15.623 & 38.623 & 2.07978 & 0.841 & 258 & 4429 & 8 & 1.1 & & 0.01 & 1045 & & 1 & 1.327 & 0.002 & 0.721 & 0.002 \\
\hline Cold spring fluid & - & - & - & - & & & - & - & & - & - & & .947 & 0.001 & 1.464 & 0.004 & - & - \\
\hline Lake Abhé water & - - & - & - & - & - & & - & - & & - & - & 137 & & 0.7 & 1.322 & 0.003 & - & - \\
\hline
\end{tabular}

${ }^{\mathrm{a}}$ Calculated

${ }^{\mathrm{b}}$ Calculated $\delta^{18} \mathrm{O}_{\mathrm{H} 2 \mathrm{O}}$ and related carbonate formation temperature [based on 2 end-member Sr-mixing calculation and recent fluid composition (this study); see text for further details].

${ }^{\mathrm{c}}$ Calculated $\delta^{18} \mathrm{O}_{\mathrm{H} 2 \mathrm{O}}$ and related carbonate formation temperature [based on 2 end-member Sr-mixing calculation and fluid composition in 1975 (Fontes et al., 1980); see text for further details].

d vs VPDB.

e vs VSMOW.

${ }^{\mathrm{f}}$ Activity ratio. All calculations for U-Th-isotopes have used the half-lives measured by Cheng et al. (2000). 